\title{
Decellularized extracellular matrix mediates tissue construction and regeneration
}

\author{
Chuanqi Liu ${ }^{1,2}$, Ming Pei ${ }^{3}$, Qingfeng Li $(\bowtie)^{2}$, Yuanyuan Zhang $(\bowtie)^{4}$ \\ ${ }^{1}$ Department of Plastic and Burn Surgery, West China Hospital, Sichuan University, Chengdu 610041, China; ${ }^{2}$ Department of Plastic and \\ Reconstructive Surgery, Shanghai Ninth People's Hospital, Shanghai Jiao Tong University School of Medicine, Shanghai 200011, China; \\ ${ }^{3}$ Stem Cell and Tissue Engineering Laboratory, Department of Orthopaedics, West Virginia University, Morgantown, WV 26506, USA; ${ }^{4}$ Wake \\ Forest Institute for Regenerative Medicine, Wake Forest University Health Sciences, Winston-Salem, NC 27109, USA
}

(C) The Author(s) 2021. This article is published with open access at link.springer.com and journal.hep.com.cn

\begin{abstract}
Contributing to organ formation and tissue regeneration, extracellular matrix (ECM) constituents provide tissue with three-dimensional (3D) structural integrity and cellular-function regulation. Containing the crucial traits of the cellular microenvironment, ECM substitutes mediate cell-matrix interactions to prompt stemcell proliferation and differentiation for 3D organoid construction in vitro or tissue regeneration in vivo. However, these ECMs are often applied generically and have yet to be extensively developed for specific cell types in 3D cultures. Cultured cells also produce rich ECM, particularly stromal cells. Cellular ECM improves 3D culture development in vitro and tissue remodeling during wound healing after implantation into the host as well. Gaining better insight into ECM derived from either tissue or cells that regulate 3D tissue reconstruction or organ regeneration helps us to select, produce, and implant the most suitable ECM and thus promote 3D organoid culture and tissue remodeling for in vivo regeneration. Overall, the decellularization methodologies and tissue/cellderived ECM as scaffolds or cellular-growth supplements used in cell propagation and differentiation for 3D tissue culture in vitro are discussed. Moreover, current preclinical applications by which ECM components modulate the wound-healing process are reviewed.
\end{abstract}

Keywords decellularized extracellular matrix; 3D culture; organoids; tissue repair

\section{Introduction}

As a three-dimensional (3D) network in biology, extracellular matrix (ECM) provides a microenvironment to cells for homeostasis, ingrowth, tissue formation, and repair [1]. Each tissue or organ has its own ECM with a distinct composition, which is generated in the early stages of embryonic development and constantly remodeled to control 3D tissue homeostasis [2]. Tissue-specific ECM offers optimal cell-cell and cell-ECM interactions by mimicking native signaling events [3]. Cell-ECM interactions are crucial for modulating cell behaviors, functions, and fates [4]. During tissue repair, quantitative and qualitative changes occur in ECM compounds during 3D tissue remodeling, which is regulated by specific enzymes, including matrix metalloproteinases (MMPs) [5].

Received April 28, 2021; accepted September 23, 2021

Correspondence: Yuanyuan Zhang, yzhang@wakehealth.edu; Qingfeng Li, dr.liqingfeng@shsmu.edu.cn
The principle of cell-based bioengineering aims to (1) develop in vitro 3D culture models, such as organoid formation; and (2) regenerate damaged tissues and organs with a combination of cells and ECM scaffolds. Previous studies have reported the use of various synthetic scaffolds mimicking the 3D ECM for tissue regeneration. For example, the pLOXL1-Lipo@PLCL-HA co-delivery system reportedly promotes pelvic-floor repair in rabbits [6], and $3 \mathrm{D}$ electrospun short fibrous sponges are demonstrated to possess good 3D adhesion onto chronic diabetic wounds in rats [7]. However, clinical applications for biomaterials remain hampered probably because of the "inertness" of synthetic ECM scaffolds [8,9]. Conversely, natural ECM contains useful structural and biochemical information, providing sufficient bioactive cues to trigger cell functions needed for tissue regeneration [10,11]. Natural ECM scaffolds are generated from decellularized ECM (dECM), either from decellularized cells (C-ECM) or decellularized tissue-specific ECM (TS-ECM) [12].

Considering the numerous advantages of dECM for cell growth and differentiation because of the retention of 
biochemical cues, dECM products have become an attractive platform for several bioengineering applications [13]. Nowadays, dECM applications in pioneering scaffold-manufacturing techniques such as 3D cell printing and electrospinning also bring the field closer to clinical translation. 3D cell printing, also known as bioprinting, enables the recapitulation of the unique features of human tissues and organs through the design of bioink and polymerization techniques [14,15]. Bioink is a formulation of cellular components and biomaterials [14,16]. These biomaterials could satisfy the requirements to print cellladen constructs; however, tissue- and organ-specific dECM-based bioinks can recapitulate a cell-supportive microenvironment niche in 3D cell-printed constructs [16]. The use of the bioprinting method for printing of cell-laden structures can reportedly provide an optimized microenvironment for 3D-structured tissue growth [17]. Thus, the new paradigm of dECM-based bioinks has been deemed as a powerful modern technology. Recently, electrospinning has attracted notable attention as another scaffold manufacturing technique. Electrospinning is a high-throughput technique that fabricates high-porosity fibrous scaffolds with nano-/microsized ultrafine fibers, whose morphology and structure mimic those of natural ECM $[13,18,19]$. The retention of architecture in electrospinning is beneficial for cell growth and alignment, but the biomechanical components in AECM may play a great role in cell differentiation [13]. Moreover, dECM is often difficult to scale up to clinically desired shapes due to its physiochemical properties. Thus, the combination of dECM and electrospinning can reduce the limitations of dECM scaffolds and provide them with tunability.

Despite the broad use of ECM, its exact mechanisms for tissue repair remain elusive. This review discusses the characteristics and mechanisms of tissue- or cell-specific ECM, along with the preparation for 3D organoid models and preclinical applications of tissue repair. Furthermore, we address challenges in clinical application and future directions.

\section{Physiologic roles of TS-ECM in organ formation}

ECM remodeling is crucial to organ formation and development. Among various organs, the intestine is an example of how ECM regulates normal organ morphogenesis [5]. In anurans tadpoles, the basement membrane of the tubular intestine thickens during intestinal metamorphosis. When induced by thyroid hormone, ECM proteins (including collagen, laminin, and fibronectin) increase, thereby inhibiting epithelial cell apoptosis in tadpoles [20]. Similarly, ECM remodeling is observed to play a central role in intestinal morphogenesis in rat [21] and mouse [22] models. Alternatively, other organs such as the lungs and the mammary and submandibular glands develop by epithelial branching. The branching process establishes the structure of these organs, and this process involves the repetitive formation of epithelial clefts and buds. The formation invades adjacent embryonic ECM, and the ECM composition and distribution shift over time. Thus, ECM remodeling provides structural integrity and regulates multiple cellular processes, such as cell growth, cell motility, and cell shape [23]. Meanwhile, the dysregulation of ECM components, structure, stiffness, and abundance may contribute to pathological conditions and exacerbate disease progression. For example, heavy scar formation is associated with abnormal ECM deposition [24], whereas osteoarthritis is linked to excessive ECM degradation [25].

\section{ECM composition}

ECM displays a 3D macromolecular network providing both structural support and biomechanical signaling to mediate cell behaviors, such as adhesion, proliferation, migration, and differentiation [26-28]. ECM consists of collagens, fibronectin (FN), laminins, elastin, proteoglycans (PGs), glycosaminoglycans (GAGs), and several other glycoproteins [29].

In mammalian tissues, ECM is generally divided into two types based on location and composition: (1) the interstitial connective tissue matrix, which surrounds and supports most stromal cells, thereby providing structural scaffolding for tissues, such as skeletal, and smooth muscle tissues [5]; and (2) the basement membrane, which primarily supports the epithelium and separates it from the environmental stroma, such as tubular and hollow structure tissues [5,30]. Although the ratios of ECM composition and structure vary among different organs or tissues, common biomacromolecules have been extensively studied (Table 1). The most dominant and abundant protein within tissue ECM is collagen [31]. Specifically, collagen type I functions in forming fibrils, collagen type II is rich in cartilage, and collagen type IV serves as a constituent part of the basement membrane [32]. Collagen types I and II are the main components of ECM. FN is a ubiquitous ECM glycoprotein that plays a critical role in attaching onto cells through binding between ligands and receptors. Thus, FN can provide molecules within the ECM with adhesion sites, such as collagens, integrins, proteoglycan, and heparan sulfate [29]. Laminins also serve as adhesive sites for ECM biomacromolecules and receptors located on the cell surface [29]. Elastin fibers are large ECM structures that undergo repeated stretching forces and thus provide recoil to tissues [33]. GAGs are usually covalently bonded to proteins to form PGs, which are vital molecules in tissue development and homeostasis [34]. Hyaluronan (HA) is a linear form of GAG containing repetitive disaccharide units of $\mathrm{N}$-acetyl-D-glucosamine and D-glucuronic acid. As a major constituent of the pericellular matrix of many cell types, HA attaches onto its cellular receptors or binds to its own synthases, thereby 
influencing various cell functions [35].

The composition of ECM is constantly updated. Matrixbound nanovesicles, a subgroup of extracellular vesicles, have been recently found within ECM. They are embedded within it and have a tissue-specific microRNA cargo and membrane lipid structure that can play a significant role in the regulation of inflammation and healing processes [40].

\section{Role of ECM in inducing stem-cell fate}

Accurately guiding stem cells to give rise to target cells is challenging due to the lack of defined inductors. As a natural niche, ECM provides a dynamic microenvironment for cell replication and differentiation when stem cells are activated [36]. The dynamic interaction in the microenvironment is also deemed as "dynamic reciprocity" [41]. With cell-ECM communication, ECM regulates stem-cell fate through structural support, biochemical composition, growth factors, and biomechanical factors [4] (Fig. 1) (Table 2).

First, ECM provides structural support for cells primarily because of the following: (1) the 3D structure of ECM allows an interconnected porous structure, and (2) the cross-linked fibrillar network and other large molecules provide rich cell-adhesion points [42]. Structural support is essential for cell adhesion, growth, and differentiation [43]. In 2020, Satyam et al. [44] reported a cell-derived ECM platform that could support podocyte proliferation, differentiation, and maintenance of the native phenotype.

With regard to biochemical composition, cells interact with the biochemical composition of ECM through transmembrane receptors. Integrins are the predominant transmembrane receptors on the surface of cells, connecting ECM proteins to the cytoskeleton within cells. They play crucial roles in various cellular activities, such as adhesion, proliferation, migration, differentiation, and homing [45-49]. Various integrin types are associated with the interactions between the cells and ECM, such as integrin $\alpha 6 \beta 1$, integrin $\alpha 9$, integrin $\beta 1$, and integrin $\alpha v \beta 3$ [48]. In 2020, Lu et al. [50] reported that integrin $\beta 1$ knockout inhibits induced pluripotent stem cells (iPSCs)' adhesion and migration across activated endothelial monolayers. In 2021, Han et al. [51] demonstrated that anti-human integrin $\beta 1$ antibody could specifically target human iPSCs and differentiate into various lineages in a mouse model.

Furthermore, ECM proteins can bind and regulate growth-factor bioavailability, serving as a growth-factor reservoir. ECM proteins such as FN, collagens, and PGs alone or combined with heparin sulfate can connect to various growth factors, such as fibroblast growth factor (FGF), hepatocyte growth factor (HGF), and vascular endothelial growth factor (VEGF) [52]. Compared with unbounded growth factors, binding with ECM can potentiate their bioactivity. The phenomenon has already been observed in HGF, bone morphogenic protein (BMP)2 and -4 , acidic FGF, and insulin like growth factor (IGF)-1 $[42,53]$. ECM can also serve as microanatomic compartments. For example, due to the restrictions of basement membrane, asymmetric sequestration of bioactive factors occurs [52]. Thus, decellularized ECM having specific interactions with growth factors may generate dynamic and functional niches. In 2019, Ullah et al. [54] reported that replenishing human kidney ECM with VEGF results in more efficient differentiation of human iPSCs into endothelial cells (ECs).

Biomechanical factors including physical and mechanical forces can modulate the topography and microstructure of ECM in the local stem-cell microenvironment. Biomechanical factor changes can lead to variations in stem-cell shape and geometry. The microstructure of

Table 1 Composition of ECM

\begin{tabular}{lll}
\hline ECM protein & Tissue sources & Functions \\
\hline Collagen & & $\begin{array}{c}\text { Resists tensile and shearing forces, affects various cellular } \\
\text { functions [29,36] }\end{array}$ \\
$\begin{array}{l}\text { Collagen I }(80 \%) \\
\text { Collagen II }\end{array}$ & $\begin{array}{l}\text { Skin, tendon, internal organs, organic parts of bone } \\
\text { Collagen III }\end{array}$ & \\
Collagen IV & Bone marrow, lymphoid tissues & \\
Collagen V & Basement membrane & \\
Fibronectin & Hair, surfaces of cells & \\
Laminin & Plasma, surfaces of cells & Cell adhesion sites, influences cellular behaviors [29,37] \\
Elastin & Basal lamina, placenta & Cell adhesion sites [29] \\
& Blood vessels, ligaments, skin, lung, bladder, elastic & Recoil [33] \\
Proteoglycans & cartilage & Resists compressive forces, provides recoil and participates in \\
& Connective tissues, intracellular compartments, surfaces \\
Hyaluronan & of cells & cell signaling and cellular behaviors [29,36] \\
& Placenta, amniotic fluid, vitreous body, articular cartilage, & Lubricates, absorbs shock, affects cellular behaviors and \\
dermis of skin & signaling molecules [38,39]
\end{tabular}




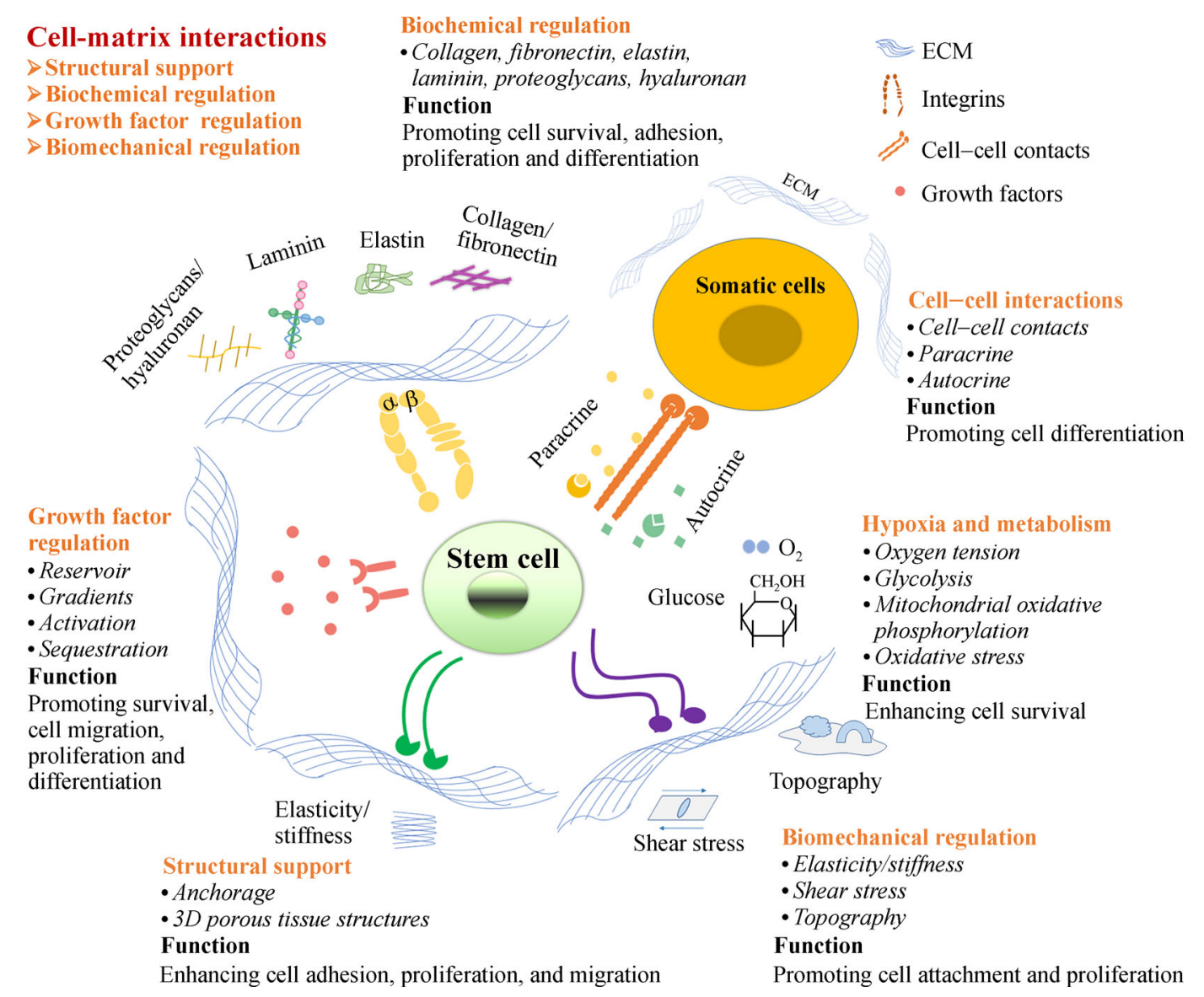

Fig. 1 Role and composition of stem-cell niche. The stem-cell niches retain the stemness of adult stem cells in a quiescent state. When tissue is injured, the surrounding microenvironment actively signals stem cells to promote either self-renewal or differentiation to form new tissues. The niches include cell-matrix, cell-protein, protein-matrix, cell-cell interactions, hypoxia, and metabolism. Among these niche factors, cell-matrix interactions play a key role in prompting cell adhesion, migration, proliferation, and differentiation for tissue regeneration. The matrix regulates stem-cell behavior through structural supports, biochemical signaling, growth factor induction, and biomechanical regulation during tissue repair.

Table 2 Role of ECM in inducing stem-cell fate

\begin{tabular}{lll}
\hline Role & Mechanism(s) & Function(s) \\
\hline Structural support & Porosity, mechanical properties, & Regulating cell adhesion, growth, differentiation and forming 3D tissue \\
structures [43] & cell-matrix communication \\
Biochemical regulation & Integrins & $\begin{array}{c}\text { Regulating cell proliferation, adhesion, migration, differentiation, homing } \\
{[45,46,49,64]}\end{array}$ \\
Growth factor regulation & Reservoir, gradients, sequestration, & $\begin{array}{c}\text { Regulating growth factor bioavailability dynamically [52]; maintaining } \\
\text { stem-cell survival, self-renewal, differentiation [64-66] }\end{array}$ \\
Biomechanical regulation & activation, autocrine, paracrine & Modulating cell shape, tissue elongation, cell-ECM interactions; regulating \\
& ECM topography, microstructure, & stem-cell fate [55-57,59,62-64] \\
\hline
\end{tabular}

substrates could reportedly affect ECM protein binding $[55,56]$. Additionally, ECM stiffness has been identified as an important element in determining stem-cell fate in terms of lineage commitment $[57,58]$ and self-renewal capacity [59]. For mesenchymal stem cells (MSCs), increased substrate stiffness enhances the osteogenic differentiation of MSCs $[60,61]$, whereas soft matrix is inclined to induce chondrogenesis and adipogenesis [3]. ECM elasticity is another factor. In 2018, Hirata et al. [62] reported that the cardiac differentiation of iPSCs prefers highly elastic substrates in vitro. In 2020, Muncie et al. [63] demonstrated that substrates recapitulating embryo elasticity could promote human embryonic stem cells (ESCs) selforganization. 
Recently, we have developed 3D human cell-based systems to replace the use of two-dimensional (2D) cell culture or animals for studying renal cytotoxicity [64]. To induce human urine-derived stem cells into renal tubular epithelial cells in 3D organoid culture, decellularized porcine kidney ECM is used as a culture supplement. Their results demonstrated that the levels of renal injury markers (CYP2E1 and KIM-1) in 3D organoids significantly increase in response to nephrotoxic agents (acetone and cisplatin). This 3D culture system with human stem cells and kidney-tissue ECM offers an alternative approach to renal-cytotoxicity testing [64].

\section{Preparation of dECM}

Decellularization is a bioengineering technology used to isolate ECM scaffold from the cells inhabiting it. The ECM scaffold product possesses bioactive molecules from native tissue, which can be used for tissue regeneration and disease remodeling. The goal of ECM decellularization is to retain ECM compounds and structure and remove xenogeneic cell compounds, thereby avoiding immunoreaction. Thus, assessing changes quantitatively and qualitatively in ECM is critical. ECM can also be mediated by certain enzymes, which are responsible for ECM degradation after implantation in vitro, such as MMPs. Currently, commercially used ECM scaffolds are applied in wide-ranging bioengineering applications and are typically divided into C-ECM and TS-ECM (Table 3).

\section{Decellularization of cell-derived ECM}

With various available treatments for decellularization, the careful monitoring of the combinations of physical, chemical, and enzymatic treatments is essential for the retention of the biochemical, biological, and biophysical properties of ECM [12]. Each of these methods may inflict damage to the structure and components of ECM, but no unified criteria exist for decellularization. Physical decellularization methods may be sufficiently harsh to alter ECM protein structures (e.g., collagen) and mechanical properties [67-70]. Chemical methods may break the connections between DNA and proteins, destroy the

Table 3 Methodology of decellularized tissue or cell-derived ECM

\begin{tabular}{|c|c|c|}
\hline Agents/techniques & Mode of action & Effects on ECM \\
\hline \multicolumn{3}{|l|}{ Physical treatments } \\
\hline Freeze and dry & $\begin{array}{l}\text { Xenogeneic cellular compounds can be washed away } \\
\text { after microscopic ice crystals disrupt cell membrane }\end{array}$ & Disrupt or fracture ECM fibers [92-94] \\
\hline $\begin{array}{l}\text { Mechanical-shaking } \\
\text { force }\end{array}$ & Shaking action promotes cell debris removal from matrix & $\begin{array}{l}\text { Disrupt ECM structure and clean up the cellular fragments } \\
\text { [95-97] }\end{array}$ \\
\hline NTIRE & Electrical pulse disrupts cellular membranes & Can disrupt ECM $[98,99]$ \\
\hline $\mathrm{scCO}_{2}$ & $\begin{array}{l}\text { Deeply penetrates into tissues and solubilizes non-polar } \\
\text { molecules }\end{array}$ & $\begin{array}{l}\text { Can disrupt ECM when the system is rapidly depressurized } \\
\text { [81] }\end{array}$ \\
\hline \multicolumn{3}{|l|}{ Chemical treatments } \\
\hline Acids and bases & Disrupts both intracellular organelles and cell membranes & $\begin{array}{l}\text { Break down collagen and GAGs and denature proteins or } \\
\text { growth factors }[95,100]\end{array}$ \\
\hline Ionic detergents & Solubilizes plasma membranes and nuclear membranes & $\begin{array}{l}\text { Denature proteins via damaging bonds between proteins } \\
{[82,101,102]}\end{array}$ \\
\hline Non-ionic detergents & $\begin{array}{l}\text { Disrupts bonds between lipids and between lipids } \\
\text { and proteins }\end{array}$ & $\begin{array}{l}\text { Beneficial to keep the ECM intact, may disrupt ultrastructure } \\
\text { and GAGs }[83,101,102]\end{array}$ \\
\hline \multicolumn{3}{|l|}{ Enzymatic treatments } \\
\hline Trypsin & Cleaves cell adhesion from ECM & $\begin{array}{l}\text { Extended exposure can destroy the structure of ECM, remove } \\
\text { fibronectin, laminin, elastin, GAG [103-105] }\end{array}$ \\
\hline Dispase & Cleaves collagen IV and fibronectin & $\begin{array}{l}\text { Extended exposure can destroy the ultrastructure of ECM } \\
{[95,106]}\end{array}$ \\
\hline $\begin{array}{l}\text { Nuclease } \\
\text { (DNase and RNase) }\end{array}$ & Degrades nucleic acids & Hard to remove, may induce immune reaction [107-109] \\
\hline $\begin{array}{l}\text { FBS (serum containing } \\
\text { DNase and RNase) }\end{array}$ & Retains bioactive proteins, degrades remaining DNA/RNA & $\begin{array}{l}\text { Can minimize the loss of major bioactive proteins, decrease } \\
\text { xenogeneic immune response [ } 86-88]\end{array}$ \\
\hline \multicolumn{3}{|l|}{ Combined methodologies } \\
\hline Shaking action + FBS & $\begin{array}{l}\text { Optimizes approaches to remove xenogeneic cellular } \\
\text { compounds by maintaining bioactive proteins and } \\
\text { ECM structure }\end{array}$ & \\
\hline
\end{tabular}

ECM, extracellular matrix; GAGs, glycosaminoglycans; NTIRE, non-thermal irreversible electroporation; $\mathrm{scCO}_{2}$, supercritical carbon dioxide; FBS, fetal bovine serum. 
ultrastructure and growth factors, and denature ECM proteins [3,67,71-75]. Enzymes such as collagenase, lipase, trypsin, dispase, thermolysin, and nucleases $[76,77]$ can remove cell residue or undesirable ECM components with high specificity. However, one limitation of enzymatic treatment is incomplete cell removal and impairment of recellularization [76]. Enzymatic treatments are insufficient for cell removal alone, so they are often combined with chemical detergents. Specific decellularization methods need to be optimized according to specific cell types, cell density, and ECM thickness [76]. Decellularization treatments are introduced systematically in the following section.

\section{Decellularization of tissue-specific ECM}

In TS-ECM, many decellularization methods are designed to remove all cellular components [78,79]. The ideal procedure is to lyse cells and then wash away the cellular compounds from the tissue while retaining the ECM components and bioactive molecules. Thus, TS-ECM products retain natural ECM properties to form bioengineered tissues. After decellularization, the xenogeneic ECM scaffold could be recellularized with stem or progenitor cells, which differentiate into the original cell types in the tissue. Given their diverse applications for tissue regeneration, decellularization techniques must be tailored and integrated to meet the requirements for specific tissues. Decellularization methods that have been investigated include physical, chemical, and enzymatic treatments. Although some are commonly used, the optimal combination for decellularization depends on the tissue's origin, characteristics, and intended use [76]. As for perfusion and immersion decellularization techniques applied to organs or tissues, they are applicable for tissues with extensive vasculature.

\section{Physical treatments}

The most common physical methods used for decellularization are to lyse or break the cell membrane or remove cells from the tissue matrix through temperature changes, mechanical force, and non-thermal irreversible electroporation (NTIRE). The mechanism involved in temperature methods is rapid freeze and thaw. After cell lysis, liquefied chemicals are used to treat the tissue. The purpose of this step is to degrade and wash out undesirable components. Temperature methods retain the ECM physical structure and are most suitable for strong and thick tissues. Mechanical-shaking force is commonly applied to organs with natural planes of dissection, such as the urinary bladder and the small intestine [80]. NTIRE is another alternative to lyse cells by using electrical pulses, which can disrupt the plasma membrane. However, NTIRE technology is suitable only for small tissues.
Interest in supercritical fluid technology to decellularize tissues is also growing. Supercritical carbon dioxide $\left(\mathrm{scCO}_{2}\right)$ easily penetrates into biological tissues, thereby facilitating the removal of structural components of cellular membranes (lipids). The main advantages of this protocol are the significant reduction in processing time and the sterilizing effects. Nevertheless, the high pressure in a reactor can lead to the rupture of cells with subsequent removal of cellular fragments when the system is rapidly depressurized [81].

\section{Prevalent chemical treatments}

The appropriate chemical detergents are selected based on the tissue's/organ's thickness, ECM composition, and intended use. The prevalent chemical detergents used for decellularization include acids, bases, ionic detergents, and non-ionic detergents.

Acids and bases are used for solubilizing cellular cytoplasmic components and removing nucleic acids, including RNA and DNA. These chemicals can effectively disrupt both intracellular organelles, cell membranes, and some important molecules, including GAGs. Ionic detergents are used for effectively solubilizing plasma membranes and nuclear membranes by breaking proteinprotein interactions [82]. Sodium dodecyl sulfate (SDS) is commonly used because it can effectively lyse cells while not damaging ECM significantly. Right after the cell membranes are lysed by SDS, the genetic contents are degraded by endonucleases and exonucleases. Non-ionic detergents disrupt lipid-lipid and lipid-protein interactions but leave protein-protein interactions intact. Triton X-100 is the most widely used non-ionic detergent [83].

\section{Enzymatic treatments}

Enzyme methods are used to destroy attachments between nucleic acid bonds. They interact with cells via adjacent proteins or other components of the cells. Collagenase, lipase, trypsin, dispase, thermolysin, and nuclease have been used to remove cells [76]. Serum has also been successfully used for decellularization due to the existence of nucleases [30].

Collagenase is appropriate for producing ECM scaffolds only when unbroken collagen structures are not required. Lipase is applicable when generating decellularized skin scaffolds. The function of lipase acids in the decellularization of skin dermis is degreasing and breaking the bonds among lipidized cells. Trypsin, a kind of serine protease, is also a common enzymatic agent for decellularization. Dispase is effective in separating undesired cells from ECM scaffold for its use in preventing cell aggregation. However, enzymes such as dispase and thermolysin are ineffective for removing cells inside tissues; they are more effective in combination with mechanical abrasion for 
complete cell removal [84]. Nucleases including DNase and RNase are often used for the cleavage of nucleic acids. Thus, nucleases are usually used to remove nucleic acids after cell lysis with physical pressure and chemical detergents [85].

Serum is commonly used in cell-culture systems because it contains many essential components that are beneficial for cell growth and propagation. The most extensively used serum is fetal bovine serum (FBS). Serum also contains serum nucleases, which can degrade the DNA and RNA remaining after cell lysis. Utilizing serum in decellularization methods has two extraordinary advantages: (1) retaining bioactive molecules in ECM compared with other reagents for decellularization [86]; and (2) degrading the DNA and RNA remaining after cell lysis, which can potentially induce immune responses [8688].

In summary, the optimal decellularization approach is to minimize the loss of major bioactive matrix components and the xenogeneic immune responses simultaneously $[30,80]$. Single or combined decellularization methods are applied to achieve optimal efficiency according to the features of specific tissues and organs.

\section{Handling of decellularized scaffolds}

Decellularization yields multiple kinds of decellularized scaffolds, which can be further recellularized for in vitro and in vivo studies. Decellularized scaffolds are deemed the final products if the original ECM architecture is well retained [89]. Furthermore, decellularized C-ECM could be used in either its original format, or it can be fragmented, ground, or solubilized. Either 2D ECM sheets or complicated 3D structures comprising 3D scaffolds can be produced from these formats [12]. In other cases, postprocessing techniques are needed to produce various products and thus meet research and clinical requirements, including the lyophilization, milling, and digestion of ECM, resulting in an injectable hydrogel [90]. It can be further cross-linked with genipin or glutaraldehyde to enhance the integrity [91].

\section{Applications of dECM}

Considering the desired functions of ECM in mediating cellular behaviors, $\mathrm{dECM}$ is extensively used as a coating agent in $2 \mathrm{D}$ or $3 \mathrm{D}$ scaffolds [110]. Its utility in tissue regeneration and stem-cell lineage induction has now been widely examined among different tissues and organs. Based on the ECM source, we discuss the applications of C-ECM and TS-ECM separately.

\section{Cell-derived ECM}

$\mathrm{C}$-ECM is commonly used as a coating on biomaterial surfaces, but more sophisticated approaches exist. For example, the synthesis products of C-ECM can serve as 2D substrates for engineering tissues de novo or facilitating wound healing and regeneration [111]. According to different applications, C-ECM can be used as a biomaterial to regenerate tissues or promote cell-lineage commitment [111].

Compared with TS-ECM, an ideal scaffold material in tissue engineering, C-ECM is normally considered an in vitro niche, in which primary cells and MSCs can be rejuvenated to maintain their proliferation and differentiation capacity [112-114]. For instance, C-ECM has been demonstrated to refresh tissue-specific stem cells such as synovium-derived stem cells (SDSCs) [115-122], bone marrow-derived MSCs (BMSCs) [123-125], umbilical cord-derived MSCs (UCMSCs) [126,127], infrapatellar fat pad-derived stem cells (IPFSCs) [128-130], ESCs [131], periodontal ligament stem cells [132], and neural progenitor cells [133]. C-ECM also refreshes primary cells such as chondrocytes $[134,135]$, nucleus pulposus cells $[136,137]$, and hepatic cells [138] in proliferation and redifferentiation capacities (Table 4). This rejuvenation effect of C-ECM primarily occurs thorough anti-inflammation and antioxidation [121,122,126,135,139], which can reverse senescent stem cells and primary cells [127].

To explore the underlying mechanisms, adult human SDSCs are grown on C-ECM deposited by adult stem cells with varied chondrogenic capacity, including SDSCs (strong), adipose-derived stem cells (ADSCs; weak), and urine-derived stem cells (USCs; none), as well as C-ECM deposited by dermal fibroblasts (a non-stem-cell control) [119]. Despite the fact that expansion on C-ECM yields a large quantity of adult SDSCs with higher chondrogenic capacity than those on tissue-culture plastic (TCP), expansion on C-ECM deposited by SDSCs (with stronger chondrogenic capacity) yields SDSCs with less chondrogenic potential than those from other C-ECM groups. Intriguingly, SDSCs grown on C-ECM deposited by USCs display the highest expression of chondrogenic marker genes, aggrecan and type II collagen, which may be associated with the highest expression of basement membrane proteins. Furthermore, one basement membrane component, FN, has been evaluated in a recent study for its effect on the proliferation and differentiation capacity of stem cells by using CRISPR/CAS9-generated FN-knockout (FN1-KO) in human IPFSCs [129]. Wang et al. [129] found that $\mathrm{FN} 1-\mathrm{KO}$ promotes the proliferative capacity of human IPFSCs; however, this capacity is reversed during expansion on C-ECM generated by FN1-KO IPFSCs. The importance of FN in chondrogenic and adipogenic differentiation is also indicated in the FN1-KO IPFSCs and $\mathrm{FN}^{-}$matrix microenvironment.

Another interesting study is to assess the influence of CECM expansion and immortalization on stem-cell proliferation and differentiation [130]. Wang et al. [130] found 
Table 4 Applications of cell-derived ECM for in vitro tissue formation and in vivo tissue repairing

\begin{tabular}{|c|c|c|c|}
\hline Application & ECM types & $\begin{array}{l}\text { Cell types and } \\
\text { animal models }\end{array}$ & Outcomes \\
\hline \multicolumn{4}{|l|}{ Tissue regeneration } \\
\hline \multirow[t]{7}{*}{ Cartilage tissue } & Porcine SDSCs & $\begin{array}{l}\text { Porcine SDSCs } \\
\text { In vitro and in vivo } \\
\text { (13 minipigs) }\end{array}$ & $\begin{array}{l}\text { Enhancing SDSCs' expansion, chondrogenic } \\
\text { potential, and repair of cartilage defects [139] }\end{array}$ \\
\hline & $\begin{array}{l}\text { Human adult vs. } \\
\text { fetal SDSCs }\end{array}$ & Human adult SDSCs & $\begin{array}{l}\text { Promoting adult SDSCs' chondrogenic capacity by } \\
\text { fetal ECM [140] }\end{array}$ \\
\hline & Human fetal MSCs & Human adult MSCs & $\begin{array}{l}\text { Promoting adult MSCs' proliferation, multipotency, } \\
\text { and stemness [141] }\end{array}$ \\
\hline & $\begin{array}{l}\text { Porcine chondrocytes } \\
\text { vs. rabbit BMSCs }\end{array}$ & $\begin{array}{l}\text { Rabbit } \\
\text { chondrocytes }\end{array}$ & $\begin{array}{l}\text { Supporting attachment and proliferation of } \\
\text { chondrocytes [142] }\end{array}$ \\
\hline & Porcine SDSCs & Porcine chondrocytes & $\begin{array}{l}\text { Delaying chondrocyte dedifferentiation and } \\
\text { enhanced redifferentiation [134] }\end{array}$ \\
\hline & $\begin{array}{l}\text { Porcine SDSCs vs. NPCs } \\
\text { vs. SDSCs/NPCs }\end{array}$ & Porcine SDSCs & $\begin{array}{l}\text { Guiding SDSCs' differentiation toward the NP } \\
\text { lineage [137] }\end{array}$ \\
\hline & Porcine SDSCs & Porcine NPCs & $\begin{array}{l}\text { Rejuvenating NPCs in proliferation and } \\
\text { redifferentiation capacity [136] }\end{array}$ \\
\hline \multirow[t]{2}{*}{ Bone tissue } & Mouse BMSCs & $\begin{array}{l}\text { Mouse BMSCs } \\
\text { In vitro and in vivo } \\
\text { (nude mice) }\end{array}$ & $\begin{array}{l}\text { Enhancing colony formation ability and retaining } \\
\text { stemness [143] }\end{array}$ \\
\hline & Human BMSCs & $\begin{array}{l}\text { Human BMSCs } \\
\text { In vitro and in vivo } \\
\text { (nude mice) }\end{array}$ & $\begin{array}{l}\text { Stimulating MSCs' expansion and preserving their } \\
\text { properties [144] }\end{array}$ \\
\hline Nerve tissue & Rat Schwann cells & $\begin{array}{l}\text { Rat dorsal root } \\
\text { ganglion neurons }\end{array}$ & $\begin{array}{l}\text { Improving axonal growth of dorsal root ganglion } \\
\text { neurons [145] }\end{array}$ \\
\hline \multicolumn{4}{|l|}{ Lineage commitment } \\
\hline ESC differentiation & Murine ESCs line & $\begin{array}{l}\text { Undifferentiated } \\
\text { murine ESCs }\end{array}$ & Boosting early differentiation of ESCs [131] \\
\hline \multirow[t]{5}{*}{ Osteogenic differentiation } & Rat osteoblasts & Human MSCs & Inducing osteogenic differentiation [146] \\
\hline & Human BMSCs & Human BMSCs & Enhancing osteogenesis $[124,125]$ \\
\hline & Human BMSCs & Human BMSCs & $\begin{array}{l}\text { Further enhancing proliferation and osteogenesis } \\
\text { when combined with melatonin }[123]\end{array}$ \\
\hline & Human USCs & Human BMSCs (passage 8) & $\begin{array}{l}\text { Recharging BMSCs' capacity in endochondral bone } \\
\text { formation [125] }\end{array}$ \\
\hline & Human UCMSCs & Human UCMSCs & $\begin{array}{l}\text { Enhancing UCMSCs' osteogenic differentiation by } \\
\text { protecting from } \mathrm{H}_{2} \mathrm{O}_{2} \text { induced senescence [127] }\end{array}$ \\
\hline \multirow[t]{8}{*}{ Chondrogenic differentiation } & $\begin{array}{l}\text { Rabbit articular } \\
\text { chondrocytes }\end{array}$ & Human MSCs & Guiding chondrogenic differentiation [146] \\
\hline & Porcine SDSCs & Porcine SDSCs & $\begin{array}{l}\text { Promoting SDSCs' proliferation and chondrogenic } \\
\text { potential }[115]\end{array}$ \\
\hline & Porcine & Porcine SDSCs & $\begin{array}{l}\text { Maximizing SDSCs' proliferation while maintaining } \\
\text { chondrogenic potential when combined with FGF2 } \\
\text { and low oxygen [116] }\end{array}$ \\
\hline & Human fetal SDSCs & Human fetal SDSCs & $\begin{array}{l}\text { Enhancing fetal SDSCs' chondrogenic potential } \\
\text { [118] }\end{array}$ \\
\hline & $\begin{array}{l}\text { Human adult vs. } \\
\text { fetal SDSCs }\end{array}$ & Human fetal SDSCs & $\begin{array}{l}\text { Enhancing SDSCs' proliferation and chondrogenic } \\
\text { capacity in a pellet culture under hypoxia [117] }\end{array}$ \\
\hline & $\begin{array}{l}\text { Passage } 5 \text { vs. } \\
15 \text { human IPFSCs }\end{array}$ & Passage 15 human IPFSCs & $\begin{array}{l}\text { Promoting IPFSCs' proliferation and chondrogenic } \\
\text { potential by C-ECM deposited by passage } 5 \text { cells } \\
{[130]}\end{array}$ \\
\hline & Human adult SDSCs & Human adult SDSCs & $\begin{array}{l}\text { Enhancing SDSCs' chondrogenic potential } \\
\text { compared with those in ECM [121] }\end{array}$ \\
\hline & $\begin{array}{l}\text { Porcine IPFSCs } \\
\text { vs. SDSCs }\end{array}$ & Porcine IPFSCs & $\begin{array}{l}\text { Enhancing IPFSCs' proliferation and } \\
\text { chondrogenic potential in both ECM groups [128] }\end{array}$ \\
\hline Hepatic differentiation & $\begin{array}{l}\text { Human liver progenitor } \\
\text { HepaRG }\end{array}$ & Human DE cells & Aiding hepatic differentiation [138] \\
\hline
\end{tabular}

SDSC, synovium-derived stem cell; MSC, mesenchymal stem cell; BMSC, bone marrow-derived mesenchymal stem cell; NPC,nucleus pulposus cell; BM, bone marrow; ESC, embryonic stem cell; USC, urine-derived stem cell; UCMSC, umbilical cord-derived mesenchymal stem cell; IPFSC, infrapatellar fat padderived stem cell; DE, definitive endoderm. 
that human IPFSCs transduced with SV40 large T antigen (SV40LT) yields an increase in proliferation and adipogenic capacity but a decrease in chondrogenic potential. Interestingly, expansion on C-ECM generated by SV40LT transduced cells yields human IPFSCs with enhanced proliferation and chondrogenic potential but decreased adipogenic capacity. This outcome has been demonstrated to be highly relevant to the expression and distribution of basement membrane proteins.

\section{Tissue-specific ECM}

Despite similar ECM composition among different tissues and organs, subtle differences in function, ratio, architecture, and stiffness of ECM can affect cellular interactions in determining cell fate [147]. Unlike C-ECM, which can refresh tissue-specific and non-tissue-specific stem/progenitor cells and primary cells, TS-ECM tends to function as a tissue-specific scaffold for stem/progenitor cells and primary cells in most cases [26]. Even without specific differentiation media, stem or progenitor cells still possess specific cell-lineage differentiation capacity based on particular interactions between cells and ECM [148]. Thus, compared with regular TCPs or natural scaffold such as collagens, TS-ECM is superior in maintaining [149] and guiding [150] stem-cell differentiation.

Depending on their application, TS-ECM products are generally divided by different organs (bone, articular cartilage, skeletal muscle, skin, and urinary bladder), different systems (musculoskeletal system, urinary system, and digestive system), or different germ layers (endoderm, mesoderm, and ectoderm). To address differences and its superiority to C-ECM, we classify TS-ECM products into four categories, namely, cell-culture supplements, cell sheets, tubular structures, and 3D structures according to different TS-ECM characteristics and applications (Table 5).

\section{TS-ECM as supplements for in vitro $3 D$ culture constructs}

In vitro models aim to mimic the composition, ratio, and function of native tissues as closely as possible [151]. TSECM compounds could play a vital role in developing a proper in vitro cell-culture system. Compared with universal ECM such as collagen, TS-ECM can provide desirable cell-substrate interactions [147]. These interactions benefit cell proliferation and cellular functions, such as the differentiation capacity of stem or progenitor cells. Here, we focus on two post-processing products of TSECM for cell culture in vitro: powder and hydrogel. 3D matrix hydrogels often feature a soft, tissue-like stiffness and mimic the ECM that is naturally present in tissues. Using 3D ECM for cell-culture models presents several benefits as it enhances cell attachment and enables proper carrying of gases, nutrients, peptides, and proteins to the targeted cells, which promotes cell survival, proliferation, migration, and differentiation.

Tissue-like 3D cultures provide a promising tool to study the pathological changes to in vitro microenvironments. Pathogens such as viruses face varying conditions in vivo; however, suitable $3 \mathrm{D}$ tissue environments that impact pathogen spread need to be established. Recent studies [152] have developed tissue-like 3D cultures combining quantification of virus replication with imaging to study single-cell and cell-population dynamics. Investigators have analyzed human immunodeficiency virus-1 (HIV-1) spread between primary human CD4 T-lymphocytes using collagen as a tissue-like $3 \mathrm{D}$ model through computation technology. This study demonstrates that $3 \mathrm{D}$ environmental constructs restrict infection via cell-free virions but promote cell-associated HIV-1 transmission. Experimental validation identifies cell motility and density as essential determinants of the efficacy and mode of HIV1 spread in 3D culture. 3D tissue constructs represent an adaptable method for the quantitative time-resolved analyses of HIV replication, spread, and interactions under in vitro 3D conditions [152].

The separation of ECM from tissues followed by decellularization and other processes (e.g., milling, pulverizing, lyophilizing, and freezing) are typical steps for producing ECM powder. TS-ECM powder derived from skin, muscle, and liver can be used as coating substrates for promoting targeted cell proliferation and maintaining the cell phenotype of the three cell types [147]. TS-ECM hydrogel is made using solubilized enzymatic procedures [153], which retain the full biochemical complexity of native tissue. Recent efforts have focused on recapitulating a wide variety of physiochemical cues of native ECM [154]. Our studies have demonstrated that synthetic skeletal muscle ECM (mECM) hydrogel, a combination of mECM, HA-based hydrogel, and heparin (HA-Hep), significantly improves the proliferation and differentiation of skeletal muscle precursor cells (MPCs) $[30,87,88,155,156]$. Additionally, TS-ECM from skin [155], liver $[155,157,158]$, and kidney $[64,159]$ efficiently induces tissue-specific stem cells to differentiate into dermal cells, hepatocytes, and renal cells, respectively, in $2 \mathrm{D}$ or $3 \mathrm{D}$ cultures.

TS-ECM based biomaterials in the bioengineering field have developed from simply coating cell-culture substrates to native ECM-mimicking scaffold design, aiming at recapitulating the exact dynamics, composition, and structure of native ECM [160]. Based on the different morphologies and topographical structures of TS-ECM, the applications can be further divided as cell-sheet tissue regeneration, tubular organ regeneration, and $3 \mathrm{D}$ tissue regeneration. 
Table 5 Applications of tissue-specific ECM in in vitro tissue construction or in vivo tissue regeneration

\begin{tabular}{llc}
\hline Application & ECM type & Seeded \\
\hline $\begin{array}{l}\text { In vitro 3D cultures } \\
\text { Powder substrates }\end{array}$ & $\begin{array}{l}\text { Acellular rat skeletal muscle } \\
\text { ECM; acellular rat liver }\end{array}$ & $\begin{array}{c}\text { Rat muscle } \\
\text { human }\end{array}$ \\
& $\begin{array}{l}\text { ECM; acellular swine } \\
\text { skin ECM }\end{array}$ & \\
& Acellular skeletal muscle & MPCs \\
Hydrogel substrates & ECM combined with & \\
& hyaluronan-based & \\
& hydrogel and heparin & \\
Cell sheet tissue & & \\
regeneration & & \\
Skin (dermis) & Acellular human & None \\
Cornea & dermal ECM, allogeneic & \\
& Acellular porcine cornea & None \\
& ECM, xenogeneic &
\end{tabular}

Tubular organ

regeneration

Blood vessels

Acellular porcine aorta, xenogeneic

Acellular bovine pericardial ECM combined with poly propylene fumarate, xenogeneic

Esophagus

Bladder

3D organ regeneration Liver

\section{Acellular porcine SIS,} xenogeneic

Acellular porcine SIS

Acellular porcine SIS, xenogeneic

Acellular porcine SIS cross-linked with procyanidins, xenogeneic

Acellular human liver ECM, allogeneic

Acellular human liver ECM, xenogeneic

Lung

Kidney

\author{
Acellular adult rat lung \\ ECM, allogeneic \\ Acellular porcine lung \\ ECM, xenogeneic
}

Perfusion decellularization of rat kidney and mounted in a whole-organ bioreactor, autologous

Culture condition(s)

Outcomes

Promoting cell proliferation and differentiation [147]

Promoting MPCs' proliferation and differentiation [30]
Human ECs and myofibroblasts

$$
\begin{aligned}
& \text { In vivo (14 patients) [161]; } \\
& \text { in vivo ( } 2 \text { patients) [163] } \\
& \text { In vivo (10 chinchilla } \\
& \text { bastard rabbits) [164]; } \\
& \text { in vivo (six eyes of rabbits) } \\
& {[165]}
\end{aligned}
$$

None

In vitro and in vivo

(2 Lewis nude rats)

In vivo (5 patients)

In vitro

Porcine BMSCs

None, or seeded with dog UCs and SMCs

In vitro and in vivo (22 dogs)

None

In vitro and in vivo (48 New Zealand white rabbits)

hUVECs, hFLCs

LX2, Sk-Hep-1, HepG2

In vitro and in vivo (6 C57BL/6J mice)

$\begin{array}{lc}\begin{array}{l}\text { Neonatal rat lung } \\ \text { epithelial cells }\end{array} & \begin{array}{c}\text { In vitro and in vivo } \\ \text { (344 rats) }\end{array} \\ \begin{array}{l}\text { Human airway epithelial } \\ \text { progenitor cells }\end{array} & \begin{array}{l}\text { In vitro and in vivo } \\ \text { (3 pigs) }\end{array}\end{array}$

hUVECs, rat NKCs

In vitro and in vivo (68 Sprague-Dawley rats)
Reducing scar and contracture [161,163]

Biocompatible with the host's epithelium $[164,165]$
Successfully implanted subcutaneously in a rat model [176]

Remaining patent for two weeks in rat model [178]

Promoting reconstruction of functional esophageal mucosa in patients [180]

Meeting clinical-grade criteria, promising for clinical use [184]

Not achieving the desired bladder regeneration resulting in a subtotal cystectomy model as in the $40 \%$ cystectomy model [185]

Promoting in situ tissue regrowth and regeneration of rabbit bladder [187]

Decellularizing a whole liver organ for liver regeneration in vitro [201]

Showing excellent viability, motility, proliferation and remodeling of the ECM in a mouse model [204]

Engineered lungs participated in gas exchange in a rat model [85]

Demonstrating the feasibility of engineering of viable lung scaffolds in a porcine model [208]

The resulting grafts produced rudimentary urine in an orthotopic transplantation model [210]

ECM, extracellular matrix; MPC, skeletal muscle precursor cell; SIS, small intestine submucosa; EC, endothelial cell; BMSC, bone marrow-derived mesenchymal stem cell; UC, urothelial cell; SMC, smooth muscle cell; HepG2, human hepatocarcinoma cell line; hUVEC, human umbilical vein endothelial cell; hFLC, human fetal liver cell; LX2, human cell line hepatic stellate cell; Sk-Hep-1, human cell line hepatocellular carcinoma; NKC, neonatal kidney cell. 


\section{TS-ECM as cell sheet for tissue regeneration}

Xenogeneic TS-ECM scaffolds, conveniently obtained using low-cost procedures, are typically fabricated as single-planar ECM sheets used for 2D tissue regeneration, such as skin (dermis) [161-163], cornea [164,165], and urethra mucosa $[166,167]$. Decellularized small intestinal submucosa (SIS) (Fig. 2) [168], bladder submucosa, and dermal matrix show promising results as inductive substrates for repairing full-thickness burns and postburn scar contractures $[161,163,169]$. Furthermore, decellularized porcine corneas using high hydrostatic pressurization show excellent optical properties without prompting an immune reaction when implanted into rabbit corneas [170].

\section{TS-ECM for tubular organ regeneration}

TS-ECM materials can be made into tubular scaffolds,
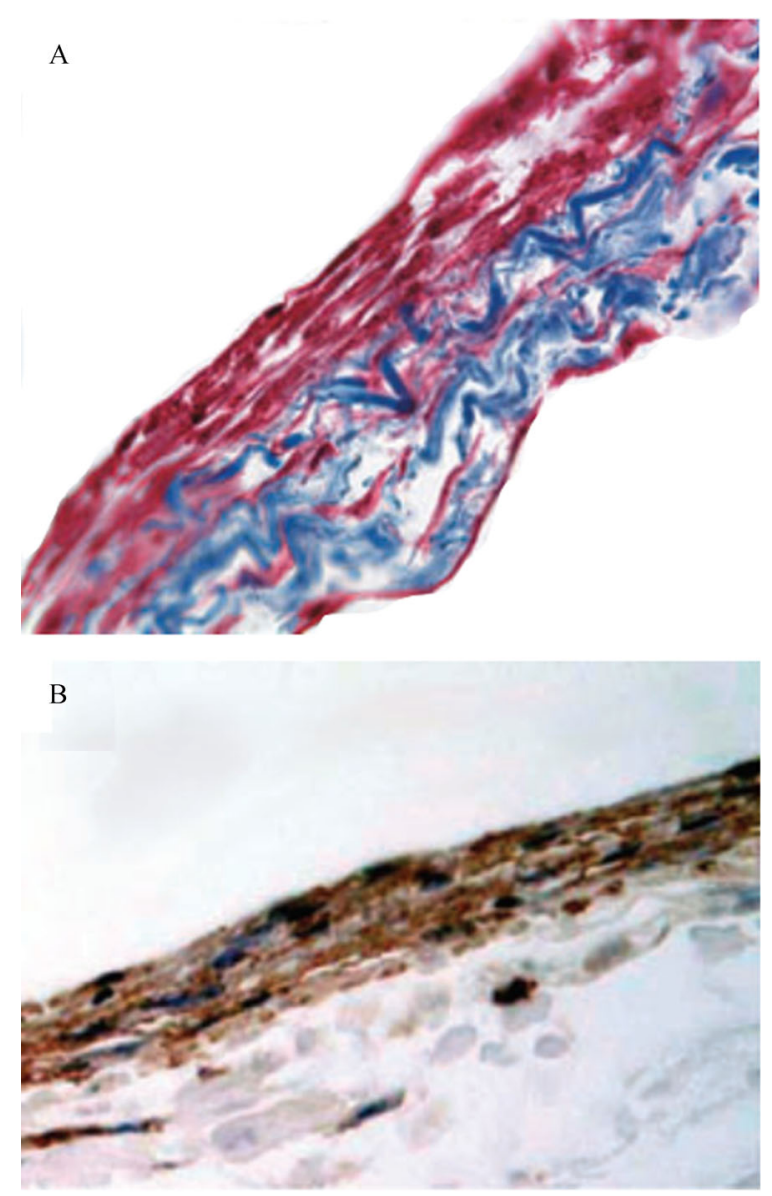

Fig. 2 Cell-seeded decellularized small intestine submucosa scaffolds. (A) Masson trichrome staining of canine bone marrow stromal stem cells (red) seeded on SIS scaffolds (blue). (B) Immunohistochemistry staining of $\alpha$-smooth muscle actin of bone marrow stromal cells (Brown). The photomicrograph of cell-seeded SIS scaffolds is adapted from $B J U$ International [168] with permission. which confer certain potential advantages, such as improved function or performance. Tubular TS-ECM can be used to regenerate blood vessels [171-178], esophagus [179-184], bladder [185-187], urethra [188,189], ureter [190], urinary conduit [191], bowel [192], and vagina [193].

SIS is one of the best established and most widely applied biomaterials [194]. Since it was reported for the first time in 1966 as a vascular substitute for replacing part of the aorta or vena cava in dog models [171-173], extensive research has been performed in the field. SISbased scaffolds show good graft patency in small-diameter grafts [195]. However, they are observed to have a deficiency in forming intima, thickening media, and dilating grafts with large diameter [174,175]. Subsequently, decellularized vessels are demonstrated as another vascular scaffold. In 2000, acellular aorta scaffold seeded with human myofibroblasts and ECs showed great success following implantation in a rat model [176]. In 2008, the decellularization and recellularization of a whole heart was shown as a functional solid organ for the first time [196]. Large- and small-diameter vascular substitutes are produced from this process, after which the vascular tree could be recapitulated by relining vascular cells [177]. A recent study has reported that the integration of pericardial dECM and poly(propylene fumarate) has robust mechanical properties, adequate re-endothelialization, and tissuegrowth capacity in vivo [178].

Research on esophageal-tissue engineering has undergone rapid development in recent years. In 2000, Badylak et al. [179] successfully repaired esophageal defects in a dog model using acellular porcine SIS or urinary bladder submucosa. In 2011, Badylak et al. [180] first reported that xenogeneic ECM derived from porcine SIS promotes functional esophageal mucosa reconstruction for patients with endoscopic resection. In the same year, Clough et al. [181] reported that acellular porcine SIS matrix successfully repairs traumatic cervical esophageal perforation. In 2014, Syed et al. [182] reported that SIS could be consistently and reliably made into tubular scaffolds with good mechanical properties for esophageal-tissue engineering. In 2018, Luc et al. [183] reported a short biologic scaffold comprising decellularized esophageal matrix in a pig model, mimicking native esophagus in in vitro and in vivo characteristics. In 2019, a clinical-grade acellular matrix study reported an esophagus decellularization process, retaining native esophageal ECM structural, biochemical, and biomechanical properties without cytotoxicity, thereby meeting clinical-grade criteria and showing promise for clinical use [184].

Urinary-tissue regeneration is anatomically divided into urinary bladder, urethra, ureter, and urinary-conduit regeneration. Application of SIS for urinary-bladder reconstruction is extensively investigated. In 1995, Kropp et al. [186] reported that SIS could promote bladder 
regeneration in a rat model. In 2005, Zhang et al. [168] confirmed the result that SIS is a promising graft for regenerating the urinary bladder in a dog model (Fig. 3). Nowadays, natural porous polymer scaffolds are produced for bladder-bioengineering applications. In 2020, Zhang et al. [187] reported that SIS cross-linked with procyanidins could rapidly promote in situ tissue regrowth and regeneration of the bladder. As for urethral regeneration, since Kropp et al. [188] reported that SIS grafts for urethroplasty promote rabbit urethral regeneration in 1998, research on urethra regeneration has grown remarkably. To date, compared with synthetic scaffolds, tubular scaffolds derived from decellularized tissues can undergo subsequent remodeling with no inflammatory response in vivo. Matrix can be derived from SIS, dermal matrix, corpus spongiosum matrix (CSM), or bladder submucosa matrix (BSM). Among these matrices, acellular CSM and BSM seem to be the most appropriate scaffolds for urethra bioengineering because they possess molecular composition and mechanical and structural characteristics similar to those of native low urinary tract tissue [189]. Similarly, tubular scaffolds applied in ureteral regeneration are produced from decellularized native-tissue specimens such as SIS, amniotic membrane, ureter, blood vessels, or bladder tissue [190]. As for constructing artificial urinary conduits, the regeneration of the urinary conduit is studied primarily in animal models, and only one registered clinical trial has examined the clinical use of artificial urinary-conduit construction (unpublished data) [191].

Similar to urinary-conduit regeneration, research on bowel and vagina regeneration is also primarily performed in animals, such as rat [192] and porcine models [193]. However, graft shrinkage and scar-tissue formation are often observed after in vivo implantation. Apparently, keeping the lumen open with physical support is critical for tubular or hollow organ-tissue regeneration. For cellseeded tissue, a promptly established blood network is required for the survival of implanted cells in the host [185]. Clearly, maintaining cell viability within ECM and preventing graft contraction after implantation require further investigation.

\section{TS-ECM for multicellular-organism regeneration in vivo}

Multicellular-organism regeneration requires a 3D framework to provide structural integrity and denote functional tissue boundaries, thereby delineating specific microenvironments [197]. Accordingly, the decellularization of whole tissues and organs provides scaffolds with tissue-specific $3 \mathrm{D}$ microarchitecture, serving as templates for wholeorgan engineering [160]. The basic strategy for transplantable human-organ generation involves the venous perfusion decellularization of human or animal organs. The

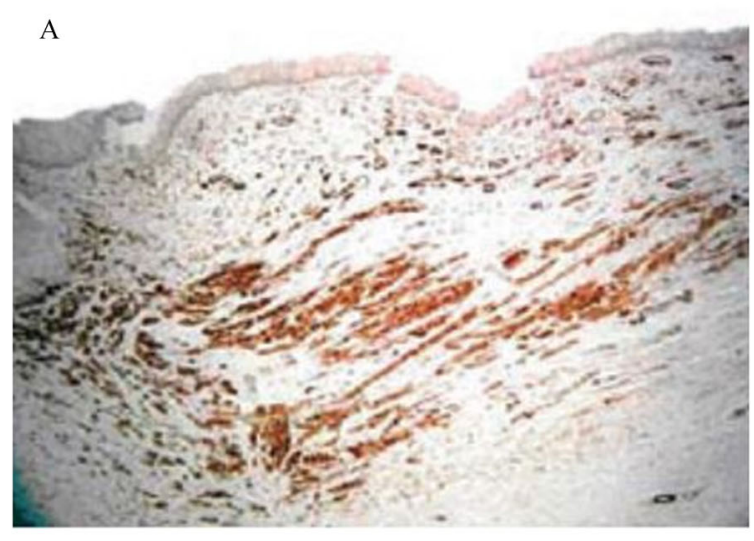

B

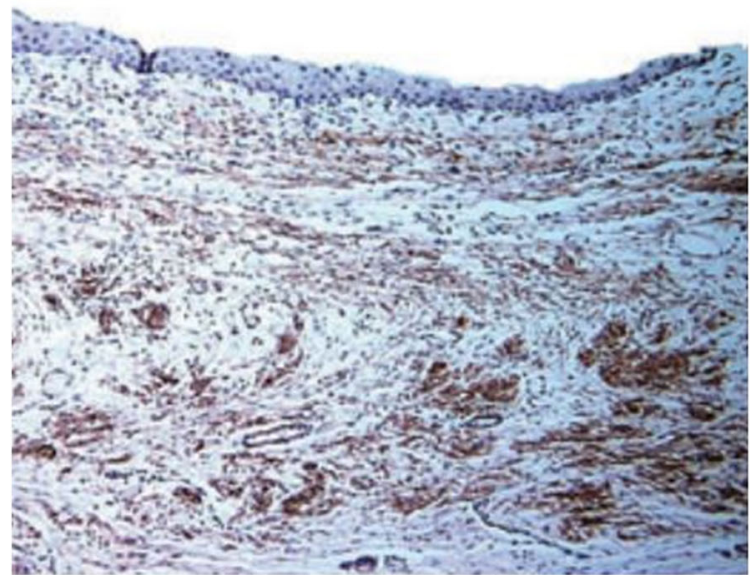

Fig. 3 Bone marrow stromal cells-seeded decellularized extracellular matrix promoted in vivo bladder tissue regeneration. Both autologous bone marrow stromal cells-seeded (A) and bladder cells-seeded SIS scaffolds (B) expressed $\alpha$-smooth muscle actin 10 weeks after transplantation in a canine model following partial cystectomy, assessed by immunohistochemistry staining. The images are adapted from $B J U$ International [168] with permission.

resulting product is a 3D framework with intact vasculature. Subsequently, the 3D scaffold is maintained in a bioreactor system to mimic the physiologic conditions of specific organs, such as electrical conduction, pressure gradients, $\mathrm{pH}$, temperature, and oxygen concentration [198]. Next, the recellularization of 3D ECM scaffold proceeds by seeding appropriate cell types in a concentration that matches that for native cell distribution. The achievement of successful perfusion decellularization was first demonstrated on a whole rat heart in 2008 [198], followed by the liver, kidney, and lungs [199].

Several studies have reported the decellularization of liver tissue from animals [199-201]. The 3D ECM framework obtained from liver tissue has been proven to retain excellent functionality of multiple liver-cell types to grow in vitro [202,203]. In 2011, Baptista et al. 
decellularized a whole cadaveric liver organ by perfusing detergent through the native-liver vascular network, fabricating a natural ECM scaffold for liver regeneration in vitro [201]. In 2015, Mazza et al. [204] decellularized a whole human liver and successfully assessed in vivo quality and biocompatibility. Later, in 2017, Verstegen et al. [205] conducted a clinical series performing the decellularization process in whole liver. They generated a mild nondestructive decellularization protocol by using perfusion through the hepatic artery and the portal vein [205]. This protocol removes cellular DNA and RNA completely and is effective for generating constructs from whole human liver. These constructs contain ECM components, and the architecture of the liver is maintained. Above all, the utilization of artificial hepatic scaffold for liver bioengineering is gaining remarkable success. However, recellularization can be further improved using innovations of more desired bioreactors to better replicate native liver.

The goal of bioengineered lungs is to rehabilitate the architecture and functionality of the two seeding routes, the vasculature and the airway [199]. In vivo gas exchange is the primary outcome for evaluating the efficiency of artificial lungs. Initially in 2010, Petersen et al. [85] demonstrated the feasibility of recellularized artificial lungs based on a rat-transplantation model. In 2011, recellularized lungs transplanted orthotopically in rats partially restored respiratory function [206,207]. In porcine models in 2017, transplanted artificial lungs promoted gas exchange [208]. However, insufficient vascular barrier function and increased thrombogenicity resulted in graft failure [208]. Functional lung regeneration still has a long way to go even though remarkable achievements have been made. To build higher-level function, optimizing the recellularization and maturation of the grafts is necessary. Moreover, experiments based on large animal models need to be performed for preclinical trials before translation to human trials.

The two primary functions of kidneys are to maintain fluid balance and filter harmful substances, which are vital for human physiologic function. For patients with endstage renal diseases, kidney transplant is deemed the firstline treatment [209]. In the kidneys, various successful decellularization and recellularization strategies have been developed. For example, rat kidneys could produce dilute urine after recellularization and culture under perfusion [210]. However, although a piece of tissue like the structure of renal components is reconstructed in vitro, the function of renal tissue with a nephron structure has not yet been determined in vivo [211]. Moreover, the current techniques still have distinct limitations in precise cell arrangement, reconstruction of an entire vascular system, and a continuous urinary-collection system. These limitations impede obtaining complete and functional wholekidney organs. Additional studies need to be conducted prior to clinical applications.

\section{Mechanisms for $3 D$ tissue regeneration}

Signaling pathways play crucial roles in substantial cellular functions (cell survival, self-renewal, attachment, proliferation, and differentiation) and tissue regeneration. Understanding the underlying signaling pathways is vital for 3D tissue regenerative repair. Key signaling pathways are involved in tissue regeneration in different systems (Table 6). These signaling pathways regulate stem-cell differentiation and 3D tissue regeneration in a complex cross-talk manner.

Recently, the Hippo signaling pathway YAP/TAZ has been shown to play a pivotal role in regulating $3 \mathrm{D}$ tissue regeneration as a new signaling pathway [273]. The core of the Hippo pathway is defined as a serine/threonine kinase cascade, comprising mammal Ste20-like kinase 1 (MST1) and MST2, Salvador 1 (SAV1), MOB1A, and MOB1B, large tumor suppressor kinase 1 (LATS1) and LATS2, the transcriptional co-activators Yes-associated protein (YAP), and transcriptional co-activator with PDZ binding motif (TAZ) [274]. The Hippo pathway is regulated by external changes of stem-cell niche factors, such as mechanical stress and cell-ECM interaction [274]. The effects of these upstream signals are mediated by receptors embedded in the cytoplasm membrane, such as integrin complex (Fig. 4). After the cells sense the signals, the Hippo pathway is regulated by an intracellular network, rather than through dedicated receptors. Thus, following injury, the Hippo pathway can act as a universal pathway to regulate stemcell behaviors for initiating tissue regeneration [273]. The Hippo pathway regulates stem-cell attachment, proliferation, self-renewal, and differentiation, such as ESCs [275], iPSCs [276,277], and MSCs [278], which are important for tissue regeneration. To date, it is reported to be involved in the regeneration of multiple organs, such as intestine [279], liver [280], skin [281], heart [241,282], and nervous system [283]. However, the downstream effects are closely associated with tumor development [284], thereby increasing the challenge in targeting the Hippo pathway for tissue regeneration.

\section{Challenges and future directions}

Tissue-derived ECM is an elemental part of the body's tissues, so it is critical to mimic its properties to develop 3D organoid models in vitro for drug screening, cell therapy, or disease modeling. Hydrogels such as collagen and matrigel are universal products extensively used as substrates for $3 \mathrm{D}$ cell cultures. However, the need for more special gels requires the development of various tissue gels. As the porosity, permeability, and mechanical characteristics of different gels vary, the natural origin of the ECM of specific tissues or organs needs to be recapitulated when these ECM gels are designed. TS-ECM compounds also need to be further characterized, 
Table 6 Mechanisms for 3D tissue regeneration

\begin{tabular}{|c|c|c|}
\hline Function & Involved signaling pathway & Cell-matrix interaction related with genes and proteins \\
\hline \multicolumn{3}{|l|}{ Musculoskeletal system } \\
\hline \multirow[t]{5}{*}{ Osteogenesis } & $\mathrm{BMP} / \mathrm{TGF} \beta$ & $\begin{array}{l}\text { Mesenchymal progenitors-BMP2-deficient mice [212], BMP4-deficient mice [213], } \\
\text { BMP7-deficient mice [214] }\end{array}$ \\
\hline & Wnt & Primary osteoprogenitors in Axin2 ${ }^{\text {LacZ/LacZ }}$ mice-Wnt protein [215] \\
\hline & & Fracture callus tissues-PTH [216] \\
\hline & & Mesenchymal skeletal cells-peptide ligand with high affinity integrin (CRRETAWAC) [217] \\
\hline & Notch & MSCs-Notch ligand (Jag1) [218-220] \\
\hline \multirow[t]{9}{*}{ Chondrogenesis } & Wnt $/ \beta$-catenin & Mesenchymal progenitors-ablation of $\beta$-catenin in mesenchymal condensations [221] \\
\hline & & Micromass of MSCs-protein kinase C inhibitor (PMA), p38 kinase inhibitor (SB203580) [222] \\
\hline & TGF $\beta /$ Smad & FSTL1 KO MSCs-exogenous recombinant FSTL1 [223] \\
\hline & & Chondrocytes-Adamts12 KO growth plate [224] \\
\hline & BMP & MSC pellets-BMP inhibitor (dorsomorphin) [225] \\
\hline & $\mathrm{BMP} / \mathrm{TGF} \beta$ & hACs and hMSCs-BMP-2, TGF $\beta 1[226]$ \\
\hline & & SDSCs-BMP-2, TGF $\beta 1$ (dexamethasone absent) [227] \\
\hline & $\mathrm{IHH}$ & Chondrocytes-PPR ${ }^{-/-}$wild-type chimeric mice vs. $\mathrm{Ihh}^{-1-} \mathrm{PPR}^{-/}$wild-type chimeric mice [228] \\
\hline & & BMSCs-IHH, SHH [229] \\
\hline \multirow[t]{5}{*}{ Skeletal myogenesis } & Wnt & Adult muscle stem cells-combining APC and $\beta$-catenin siRNAs [230] \\
\hline & & Satellite cells-Islr cKO mice [231] \\
\hline & Wnt/IGF & Satellite cell-like reserve myoblasts-GSK-3 inhibitor ( $\mathrm{LiCl}$ or SB216763), insulin [232] \\
\hline & Notch & $\begin{array}{l}\text { Adult muscle stem cells-COLV depleted mice (compound Tg: Pax7-CreERT2; Col5a } 1^{\text {floxflox }} \text {; } \\
R 26^{m T m G}(\text { Col5al cKO)), CALCR ligand (Elcatonin) injection [233] }\end{array}$ \\
\hline & & Satellite cells-Syndecan-3 ablation [234] \\
\hline \multicolumn{3}{|l|}{ Nervous system } \\
\hline \multirow[t]{5}{*}{ Neurogenesis in $\mathrm{CNC}$} & $\mathrm{PI} 3 \mathrm{~K} / \mathrm{AKT} / \mathrm{mTOR}$ & Cerebral organoids-mTOR activators (INSR, ITGB8, IFNAR1) and repressors (PTEN) [235] \\
\hline & Notch & Neuronal progenitor cells-NOTCH2NL [236] \\
\hline & & hSpS spheroids-Notch inhibitor (DAPT) [237] \\
\hline & Wnt/FGF & mESCs-FGF/Wnt agonist (CHIR)/RA [238] \\
\hline & $\mathrm{TGF} \beta / \mathrm{Shh} / \mathrm{Wnt}$ & Astrocytes-TGF $\beta$, Shh, and Wnt activators [239] \\
\hline Neurogenesis in PNS & c-Myc-TERT & Sensory axon-p53 inhibitor (PFT $\alpha$ ), p53 activator (Tenovin-6) [240] \\
\hline \multicolumn{3}{|l|}{ Circulatory system } \\
\hline \multirow[t]{3}{*}{ Cardiomyogenesis } & Wnt & Cardiac organoids-Wnt agonist (CHIR) [241-243], WNT inhibitor (IWP2) [243] \\
\hline & TGF $\beta$ & $\begin{array}{l}\text { Cardiac organoids-TGF } \beta \text { receptor inhibitor (e.g., SB431542) or overexpression of TGF } \beta \\
\text { receptor negative form }[244,245]\end{array}$ \\
\hline & BMP & $\begin{array}{l}\mathrm{NKX} 2-5^{+} \mathrm{CD} 31^{+} \text {endocardial-like cells from hPSCs-BMP4, CHIR/BMP10, VEGF/BMP10 } \\
{[246]}\end{array}$ \\
\hline \multirow[t]{2}{*}{ Angiogenesis } & Notch & Vascular organoids-Notch inhibitor (DAPT), Notch ligands (D114, Notch3) [247] \\
\hline & Wnt/VEGF-A & $\begin{array}{l}\text { hPSCs aggregates-3D collagen I-matrigel gel driven by Wnt agonist (CHIR), BMP-4, VEGF-A, } \\
\text { FGF-2 subsequently [248] }\end{array}$ \\
\hline \multicolumn{3}{|l|}{ Digestive system } \\
\hline \multirow{2}{*}{$\begin{array}{l}\text { Stomach tissue } \\
\text { reconstruction }\end{array}$} & Wnt & Lgr5 $^{+}$stem cells-matrigel containing Wnt activator (R-spondin1), Wnt3A [249] \\
\hline & & Axin $2^{+} /$Lgr $5^{-}$stem cells-Wnt activator (R-spondin3) [250] \\
\hline \multirow{3}{*}{$\begin{array}{l}\text { Intestine tissue } \\
\text { reconstruction }\end{array}$} & Wnt & Lgr5 $^{+}$ISCs-Wnt activator (R-spondin1), Wnt ligands [251-253] \\
\hline & Wnt/Notch & Lgr5 $^{+}$ISCs-Wnt inhibitor (IWP-2)/Lgr5 ${ }^{+}$ISCs-Notch inhibitor (DAPT) [254] \\
\hline & Notch & ISCs-Notch ligands driven by transient Yap1 activation [255] \\
\hline \multirow[t]{4}{*}{ Hepatogenesis } & Wnt & Lgr5 $^{+}$stem cells-matrigel containing EGF, Wnt activator (R-spondin1) [256] \\
\hline & & Lgr5 $^{+}$stem cells-HGF/Wnt activator (R-spondin1) [257] \\
\hline & Hedgehog & Hepatocytes and ductular cells-Hh ligands [258] \\
\hline & & Stellate cells-JNK1 [259] \\
\hline \multicolumn{3}{|l|}{ Urinary system } \\
\hline \multirow[t]{2}{*}{ Nephrogenesis } & Wnt & $\mathrm{Lgr}^{+}{ }^{+}$stem cells-Wnt receptor $(\mathrm{Lgr} 5)[260]$ \\
\hline & & hPSCs-Wnt agonist (CHIR), Wnt inhibitor (DAPT) [261] \\
\hline
\end{tabular}




\begin{tabular}{|c|c|c|}
\hline & & (Continued) \\
\hline Function & Involved signaling pathway & Cell-matrix interaction related with genes and proteins \\
\hline \multirow{4}{*}{$\begin{array}{l}\text { Urothelium } \\
\text { regeneration }\end{array}$} & Wnt, FGF & hPSCs-Wnt agonist (CHIR), FGF9 [262,263] \\
\hline & Hedgehog/Wnt & $\begin{array}{l}\text { Stromal cells and epithelial cells in bladder-Shh-blocking antibody/stromal cells and epithelial } \\
\text { cells-inactivation of essential component of Wnt pathway (Ctnnb1) [264] }\end{array}$ \\
\hline & Hedgehog & $\begin{array}{l}\text { Long-term bladder organoids-smoothened agonist (SAG), Hh inhibitor (vismodegib), genetic } \\
\text { manipulation [265] }\end{array}$ \\
\hline & Wnt/Notch & Urothelial organoids-Wnt agonist (CHIR)/urothelial organoids-Notch inhibitor (DBZ) [266] \\
\hline \multicolumn{3}{|l|}{ Reproductive system } \\
\hline \multirow[t]{2}{*}{$\begin{array}{l}\text { Fallopian tube and } \\
\text { oviduct tissue } \\
\text { reconstruction }\end{array}$} & Wnt/Notch & $\begin{array}{l}\text { Fallopian tube organoids-Wnt modulators (Wnt3a, R-spondin1, EGF, FGF10), TGF } \beta \text { inhibitor } \\
\text { (ALK4/5), BMP inhibitor (Noggin)/fallopian tube organoids-Notch inhibitor (DBZ) [267] }\end{array}$ \\
\hline & & $\begin{array}{l}\text { Fallopian tube organoids-Wnt antagonist (PKF118-310)/fallopian tube organoids-Notch } \\
\text { inhibitor (DBZ) [268] }\end{array}$ \\
\hline \multirow[t]{2}{*}{ Endometrium } & Wnt & $\begin{array}{l}\text { Endometrial organoids-Wnt activator (R-spondin1), Wnt inhibitor (IWP2), WNT3A, WNT7A, } \\
\text { EGF, Noggin [269] }\end{array}$ \\
\hline & & Endometrial organoids-WNT3A, Wnt activator (R-spondin1), EGF, Noggin [270] \\
\hline $\begin{array}{l}\text { Vagina tissue } \\
\text { reconstruction }\end{array}$ & Wnt & $\begin{array}{l}\text { Vaginal organoids-EGF, TGFb/Alk inhibitor (A83-01), ROCK inhibitor (Y-27632), PALL } \\
\text { Corporation (Ultraserum-G) [271] }\end{array}$ \\
\hline $\begin{array}{l}\text { Prostate tissue } \\
\text { reconstruction }\end{array}$ & Notch & Prostate organoids-Notch inhibitor (DAPT) [272] \\
\hline
\end{tabular}

hAC, human articular chondrocyte; hMSC, human mesenchymal stem cell; SDSC, synovial-derived stem cell; IHH, Indian Hedgehog; PPR, PTH/PTHrP receptor; BMSC, bone marrow-derived mesenchymal stem cell; CNS, central nervous system; PNS, peripheral nervous system; hSpS, hindbrain/cervical spinal cord; mESC, mouse embryonic stem cell; ISC, intestinal stem cell;Hh, Hedgehog; hPSC, human pluripotent stem cell.

controlled, and standardized to prevent variability in either C-ECM or TS-ECM.

For tissue repair in the body, ECM plays an important role in wound healing. As a complex physiologic reaction in response to trauma, would healing involves cellular and ECM events, biochemical reactions, growth factors, and cytokines. The goal for wound healing is scar-free restoration with less tissue shrinkage. Various possibilities have rendered ECM-based scaffolding technologies a turning point in regenerative medicine. To date, animal models have demonstrated that delayed collagen-deposition paired ECM remodeling is one of the traits for scarless wound healing [285]. However, some challenges exist for preclinical animal models, such as low reproducibility, ethical problems, and poor translation to humans. Moreover, the most prominent challenge is the inconsistency between healthy ECM scaffolds and the dysfunctional matrix that is the result of injuries. Dysfunctional matrix includes decreased or excessive ECM compounds [286], often accompanied with a change in soluble factors, such as transforming growth factor $\beta$ [287] and cross-linking enzymes [288]. A proteomic study has also revealed that the composition of normal and pathological ECM exhibits a completely different profile [286]. Considering this finding, whether ECM scaffolds can provide the correct cues to regulate cell behaviors on pathological tissues is still unclear. To close the gap in knowledge, pathological ECM remodeling and genetically engineered ECM scaffolds offer two alternatives by improving the function and biocompatibility of ECM.
ECM remodeling is a healing process that offers promising therapeutic opportunities for many diseases [5]. Implanted ECM scaffold with a bioactive molecular and porous microstructure can enhance wound healing. For example, the immobilization of signaling molecules on the porous surface of scaffolds can promote cell proliferation, differentiation, and cell-matrix adhesion [289,290]. Selecting a specific enzyme to enhance tissue remodeling is important. One study has shown that curcumin treatment could accelerate wound healing by suppressing MMP-9 in a mouse model [291]. Moreover, attempts to genetically engineer ECM have achieved preliminary success in animal models. ECM sheets and hydrogels generated from porcine, which is alpha-gal deficient (with reduced immune rejection), show that 3D-generated transected anterior cruciate ligament can form in a goat model [292]. As TS-ECMs of different tissues share a common set of proteins, the role of individual ECM components in the unique functions of tissues and the healing process still needs further investigation. A robust and extensive proteomic analysis of TS-ECM components is critical to illustrate the tissue regeneration process induced by TSECM. In summary, a pro-regenerative matrix combined with the ECM remodeling of pathological tissues may bring us one step closer to scar-free tissue regeneration. TS-ECM in tissue repair could bring us closer to scarless wound healing.

In conclusion, mimicking the microenvironment of original tissues, TS-ECM and C-ECM possess remarkable promise for developing in vitro $3 \mathrm{D}$ culture systems and 


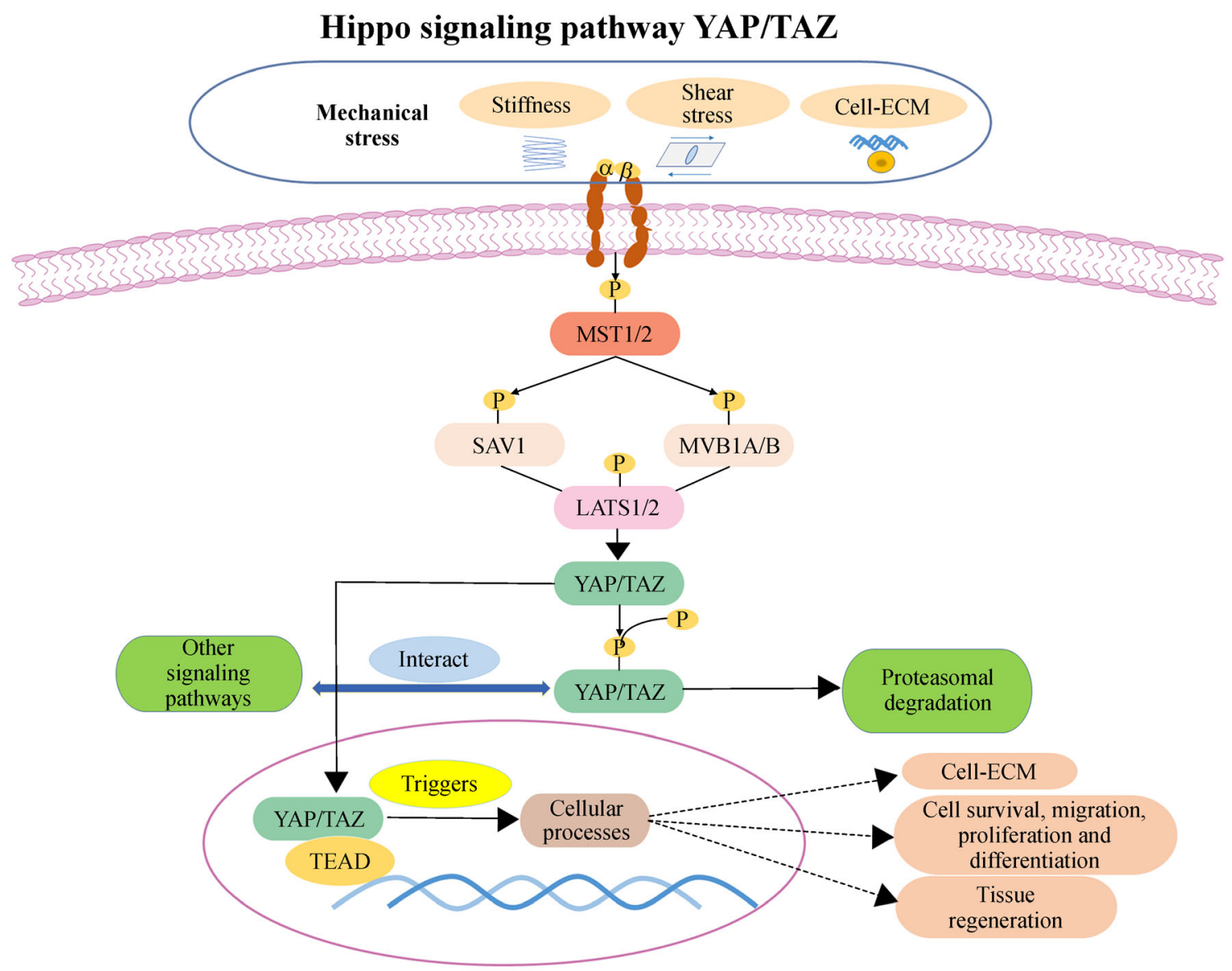

Fig. 4 Hippo signaling pathway YAP/TAZ for regulating cell behaviors and tissue regeneration. The Hippo pathway is regulated by an intracellular network relaying a multitude of external inputs. Mechanical stress and cell-extracellular matrix (ECM) adhesion changes can regulate the Hippo pathway through integrin signaling. Activation of the Hippo pathway is associated with the phosphorylation of the core Hippo pathway kinases, including mammal Ste20-like kinase 1 (MST1) and MST2, Salvador 1 (SAV1), MOB1A and MOB1B, large tumor suppressor kinase 1 (LATS1) and LATS2, the transcriptional co-activators Yes-associated protein (YAP) and transcriptional co-activator with PDZ binding motif (TAZ), which leads to proteasomal degradation. Conversely, when the Hippo kinase cascade is not activated, unphosphorylated YAP/TAZ binding with TEAD transcription factor can activate specific genes, regulating ECM remodeling, cellular behaviors (cell attachment, proliferation, migration, and differentiation) and tissue regeneration.

cell-based therapy. Tissue bioengineering in organoid constructions or $3 \mathrm{D}$ culture models offers a novel platform to study diseases and test new drugs. dECM products also provide therapeutic alternatives for the repair of injured or pathological tissues during tissue reconstruction. Compared with C-ECM, emerging evidence suggests that TSECM as a scaffold needs to be improved due to its unique biochemical, biological, and biophysical properties. This review highlights the physiologic roles of ECM in $3 \mathrm{D}$ organoid formation and tissue repair and presents the currently recognized applications of C-ECM and TS-ECM in modulating cellular construction development and organ-healing processes following tissue injury. To date, TS-ECM products have advanced to several formats such as powder, hydrogel, cell sheet, and decellularized tissue and organ for in vitro 3D structure culture models. Inevitably, tissue repair for wound healing will be refined in future applications.

The past few decades have witnessed substantial progress in TS-ECM or C-ECM developments. However, major hurdles remain in understanding the accurate and specific key ECM proteins and the ratio of these molecules for cell proliferation and targeted cell differentiation for 3D organoid culture and tissue repair. Thus, further basic research and preclinical testing are necessary before clinical translation.

\section{Acknowledgements}

We thank Ms. Suzanne Danley (Department of Orthopaedics, West 
Virginia University) for editing the manuscript. This work was partially supported by Research Grants from the National Institutes of Health (No. 1R01AR067747) to Ming Pei and by NIH/NIAID (Nos. R21AI152832 and R03AI165170) to Yuanyuan Zhang.

\section{Compliance with ethics guidelines}

Chuanqi Liu, Ming Pei, Qingfeng Li, and Yuanyuan Zhang declare that they have no conflict of interest. This manuscript is a review article and does not involve a research protocol requiring approval by the relevant institutional review board or ethics committee.

Open Access This article is licensed under a Creative Commons Attribution 4.0 International License, which permits use, sharing, adaptation, distribution and reproduction in any medium or format, as long as you give appropriate credit to the original author(s) and the source, provide a link to the Creative Commons license, and indicate if changes were made.

The images or other third party material in this article are included in the article's Creative Commons license, unless indicated otherwise in a credit line to the material. If material is not included in the article's Creative Commons license and your intended use is not permitted by statutory regulation or exceeds the permitted use, you will need to obtain permission directly from the copyright holder.

To view a copy of this license, visit https://creativecommons.org/ licenses/by/4.0/.

\section{References}

1. Prewitz MC, Seib FP, von Bonin M, Friedrichs J, Stißel A, Niehage C, Müller K, Anastassiadis K, Waskow C, Hoflack B, Bornhäuser $\mathrm{M}$, Werner $\mathrm{C}$. Tightly anchored tissue-mimetic matrices as instructive stem cell microenvironments. Nat Methods 2013; 10(8): 788-794

2. Hynes RO. The extracellular matrix: not just pretty fibrils. Science 2009; 326(5957): 1216-1219

3. Sart S, Jeske R, Chen X, Ma T, Li Y. Engineering stem cell-derived extracellular matrices: decellularization, characterization, and biological function. Tissue Eng Part B Rev 2020; 26(5): 402-422

4. Sart S, Agathos SN, Li Y. Engineering stem cell fate with biochemical and biomechanical properties of microcarriers. Biotechnol Prog 2013; 29(6): 1354-1366

5. Bonnans C, Chou J, Werb Z. Remodelling the extracellular matrix in development and disease. Nat Rev Mol Cell Biol 2014; 15(12): 786-801

6. Jin J, Saiding Q, Wang X, Qin M, Xiang Y, Cheng R, Cui W, Chen $\mathrm{X}$. Rapid extracellular matrix remodeling via gene-electrospun fibers as a "Patch" for tissue regeneration. Adv Funct Mater 2021; 31(15): 2009879

7. Correa D, Hesse E, Seriwatanachai D, Kiviranta R, Saito H, Yamana K, Neff L, Atfi A, Coillard L, Sitara D, Maeda Y, Warming S, Jenkins NA, Copeland NG, Horne WC, Lanske B, Baron R. Zfp521 is a target gene and key effector of parathyroid hormone-related peptide signaling in growth plate chondrocytes.
Dev Cell 2010; 19(4): 533-546

8. Wang X, Chang J, Wu C. Bioactive inorganic/organic nanocomposites for wound healing. Appl Mater Today 2018; 11: 308-319

9. Mano JF, Silva GA, Azevedo HS, Malafaya PB, Sousa RA, Silva SS, Boesel LF, Oliveira JM, Santos TC, Marques AP, Neves NM, Reis RL. Natural origin biodegradable systems in tissue engineering and regenerative medicine: present status and some moving trends. J R Soc Interface 2007; 4(17): 999-1030

10. Zhu M, Li W, Dong X, Yuan X, Midgley AC, Chang H, Wang Y, Wang H, Wang K, Ma PX, Wang H, Kong D. In vivo engineered extracellular matrix scaffolds with instructive niches for oriented tissue regeneration. Nat Commun 2019; 10(1): 4620

11. Li Y, Xiao Y, Liu C. The horizon of materiobiology: a perspective on material-guided cell behaviors and tissue engineering. Chem Rev 2017; 117(5): 4376-4421

12. Zhang W, Zhu Y, Li J, Guo Q, Peng J, Liu S, Yang J, Wang Y. Cell-derived extracellular matrix: basic characteristics and current applications in orthopedic tissue engineering. Tissue Eng Part B Rev 2016; 22(3): 193-207

13. Smoak MM, Hogan KJ, Grande-Allen KJ, Mikos AG. Bioinspired electrospun $\mathrm{dECM}$ scaffolds guide cell growth and control the formation of myotubes. Sci Adv 2021; 7(20): eabg4123

14. Jang J, Park JY, Gao G, Cho DW. Biomaterials-based 3D cell printing for next-generation therapeutics and diagnostics. Biomaterials 2018; 156: 88-106

15. Murphy SV, Atala A. 3D bioprinting of tissues and organs. Nat Biotechnol 2014; 32(8): 773-785

16. Kim BS, Das S, Jang J, Cho DW. Decellularized extracellular matrix-based bioinks for engineering tissue- and organ-specific microenvironments. Chem Rev 2020; 120(19): 10608-10661

17. Pati F, Jang J, Ha DH, Won Kim S, Rhie JW, Shim JH, Kim DH, Cho DW. Printing three-dimensional tissue analogues with decellularized extracellular matrix bioink. Nat Commun 2014; 5(1): 3935

18. Li Y, Wang J, Qian D, Chen L, Mo X, Wang L, Wang Y, Cui W. Electrospun fibrous sponge via short fiber for mimicking 3D ECM. J Nanobiotechnology 2021; 19(1): 131

19. Kishan AP, Cosgriff-Hernandez EM. Recent advancements in electrospinning design for tissue engineering applications: a review. J Biomed Mater Res A 2017; 105(10): 2892-2905

20. Su Y, Shi Y, Stolow MA, Shi YB. Thyroid hormone induces apoptosis in primary cell cultures of tadpole intestine: cell type specificity and effects of extracellular matrix. J Cell Biol 1997; 139(6): 1533-1543

21. Simon-Assmann P, Kedinger M, De Arcangelis A, Rousseau V, Simo P. Extracellular matrix components in intestinal development. Experientia 1995; 51(9-10): 883-900

22. Mahoney ZX, Stappenbeck TS, Miner JH. Laminin $\alpha 5$ influences the architecture of the mouse small intestine mucosa. J Cell Sci 2008; 121(15): 2493-2502

23. Kim HY, Nelson CM. Extracellular matrix and cytoskeletal dynamics during branching morphogenesis. Organogenesis 2012; 8(2): 56-64

24. Frantz C, Stewart KM, Weaver VM. The extracellular matrix at a glance. J Cell Sci 2010; 123(24): 4195-4200

25. Zhen G, Cao X. Targeting TGF $\beta$ signaling in subchondral bone and articular cartilage homeostasis. Trends Pharmacol Sci 2014; 35(5): 


\section{7-236}

26. Cheng CW, Solorio LD, Alsberg E. Decellularized tissue and cellderived extracellular matrices as scaffolds for orthopaedic tissue engineering. Biotechnol Adv 2014; 32(2): 462-484

27. Özbek S, Balasubramanian PG, Chiquet-Ehrismann R, Tucker RP, Adams JC. The evolution of extracellular matrix. Mol Biol Cell 2010; 21(24): 4300-4305

28. Michel G, Tonon T, Scornet D, Cock JM, Kloareg B. The cell wall polysaccharide metabolism of the brown alga Ectocarpus siliculosus. Insights into the evolution of extracellular matrix polysaccharides in Eukaryotes. New Phytol 2010; 188(1): 82-97

29. Theocharis AD, Skandalis SS, Gialeli C, Karamanos NK. Extracellular matrix structure. Adv Drug Deliv Rev 2016; 97: 4-27

30. Li L, Liu G, Timashev P, Sun XS, Criswell T, Atala A, Zhang Y. Biofabrication of tissue-specific extracellular matrix proteins to enhance the expansion and differentiation of skeletal muscle progenitor cells. Appl Phys Rev 2019; 6(2): 021309

31. Ricard-Blum S. The collagen family. Cold Spring Harb Perspect Biol 2011; 3(1): a004978

32. LeBleu VS, Macdonald B, Kalluri R. Structure and function of basement membranes. Exp Biol Med (Maywood) 2007; 232(9): 1121-1129

33. Wagenseil JE, Mecham RP. New insights into elastic fiber assembly. Birth Defects Res C Embryo Today 2007; 81(4): 229240

34. Kjellén L, Lindahl U. Specificity of glycosaminoglycan-protein interactions. Curr Opin Struct Biol 2018; 50: 101-108

35. Knudson CB, Knudson W. Hyaluronan-binding proteins in development, tissue homeostasis, and disease. FASEB J 1993; 7(13): 1233-1241

36. Niklason LE. Understanding the extracellular matrix to enhance stem cell-based tissue regeneration. Cell Stem Cell 2018; 22(3): 302-305

37. Avnur Z, Geiger B. The removal of extracellular fibronectin from areas of cell-substrate contact. Cell 1981; 25(1): 121-132

38. Vasvani S, Kulkarni P, Rawtani D. Hyaluronic acid: a review on its biology, aspects of drug delivery, route of administrations and a special emphasis on its approved marketed products and recent clinical studies. Int J Biol Macromol 2020; 151: 1012-1029

39. Vigetti D, Viola M, Karousou E, Deleonibus S, Karamanou K, De Luca G, Passi A. Epigenetics in extracellular matrix remodeling and hyaluronan metabolism. FEBS J 2014; 281(22): 4980-4992

40. Huleihel L, Hussey GS, Naranjo JD, Zhang L, Dziki JL, Turner NJ, Stolz DB, Badylak SF. Matrix-bound nanovesicles within ECM bioscaffolds. Sci Adv 2016; 2(6): e1600502

41. Nelson CM, Bissell MJ. Of extracellular matrix, scaffolds, and signaling: tissue architecture regulates development, homeostasis, and cancer. Annu Rev Cell Dev Biol 2006; 22(1): 287-309

42. Wei W, Li J, Chen S, Chen M, Xie Q, Sun H, Ruan J, Zhou H, Bi $\mathrm{X}$, Zhuang A, You Z, Gu P, Fan X. In vitro osteogenic induction of bone marrow mesenchymal stem cells with a decellularized matrix derived from human adipose stem cells and in vivo implantation for bone regeneration. J Mater Chem B Mater Biol Med 2017; 5(13): 2468-2482

43. Choudhury D, Tun HW, Wang T, Naing MW. Organ-derived decellularized extracellular matrix: a game changer for bioink manufacturing? Trends Biotechnol 2018; 36(8): 787-805
44. Satyam A, Tsokos MG, Tresback JS, Zeugolis DI, Tsokos GC. Cell derived extracellular matrix-rich biomimetic substrate supports podocyte proliferation, differentiation and maintenance of native phenotype. Adv Funct Mater 2020; 30(44): 1908752

45. Legate KR, Wickström SA, Fässler R. Genetic and cell biological analysis of integrin outside-in signaling. Genes Dev 2009; 23(4): 397-418

46. Li Y, Gautam A, Yang J, Qiu L, Melkoumian Z, Weber J, Telukuntla L, Srivastava R, Whiteley EM, Brandenberger R. Differentiation of oligodendrocyte progenitor cells from human embryonic stem cells on vitronectin-derived synthetic peptide acrylate surface. Stem Cells Dev 2013; 22(10): 1497-1505

47. Mathews S, Bhonde R, Gupta PK, Totey S. Extracellular matrix protein mediated regulation of the osteoblast differentiation of bone marrow derived human mesenchymal stem cells. Differentiation 2012; 84(2): 185-192

48. Kanatsu-Shinohara M, Takehashi M, Takashima S, Lee J, Morimoto H, Chuma S, Raducanu A, Nakatsuji N, Fässler R, Shinohara T. Homing of mouse spermatogonial stem cells to germline niche depends on $\beta 1$-integrin. Cell Stem Cell 2008; 3(5): 533-542

49. Brafman DA, Phung C, Kumar N, Willert K. Regulation of endodermal differentiation of human embryonic stem cells through integrin-ECM interactions. Cell Death Differ 2013; 20(3): 369381

50. Lu M, Xue R, Wang P, Wang X, Tian X, Liu Y, Wang S, Cui A, Xie J, Le L, Zhao M, Quan J, Li N, Meng D, Wang X, Sun N, Chen $\mathrm{AF}$, Xiang $\mathrm{M}$, Chen $\mathrm{S}$. Induced pluripotent stem cells attenuate chronic allogeneic vasculopathy in an integrin beta-1-dependent manner. Am J Transplant 2020; 20(10): 2755-2767

51. Han S, Kang B, Son HY, Choi Y, Shin MK, Park J, Min JK, Park $\mathrm{D}$, Lim EK, Huh YM, Haam S. In vivo monitoring platform of transplanted human stem cells using magnetic resonance imaging. Biosens Bioelectron 2021; 178: 113039

52. Brizzi MF, Tarone G, Defilippi P. Extracellular matrix, integrins, and growth factors as tailors of the stem cell niche. Curr Opin Cell Biol 2012; 24(5): 645-651

53. Ghaedi M, Duan Y, Zern MA, Revzin A. Hepatic differentiation of human embryonic stem cells on growth factor-containing surfaces. J Tissue Eng Regen Med 2014; 8(11): 886-895

54. Ullah I, Abu-Dawud R, Busch JF, Rabien A, Erguen B, Fischer I, Reinke P, Kurtz A. VEGF-supplemented extracellular matrix is sufficient to induce endothelial differentiation of human iPSC. Biomaterials 2019; 216: 119283

55. Giamblanco N, Martines E, Marletta G. Laminin adsorption on nanostructures: switching the molecular orientation by local curvature changes. Langmuir 2013; 29(26): 8335-8342

56. González-García C, Sousa SR, Moratal D, Rico P, SalmerónSánchez M. Effect of nanoscale topography on fibronectin adsorption, focal adhesion size and matrix organisation. Colloids Surf B Biointerfaces 2010; 77(2): 181-190

57. Engler AJ, Sen S, Sweeney HL, Discher DE. Matrix elasticity directs stem cell lineage specification. Cell 2006; 126(4): 677-689

58. Sthanam LK, Barai A, Rastogi A, Mistari VK, Maria A, Kauthale R, Gatne M, Sen S. Biophysical regulation of mouse embryonic stem cell fate and genomic integrity by feeder derived matrices. Biomaterials 2017; 119: 9-22 
59. Gilbert PM, Havenstrite KL, Magnusson KE, Sacco A, Leonardi NA, Kraft P, Nguyen NK, Thrun S, Lutolf MP, Blau HM. Substrate elasticity regulates skeletal muscle stem cell self-renewal in culture. Science 2010; 329(5995): 1078-1081

60. Gobaa S, Hoehnel S, Roccio M, Negro A, Kobel S, Lutolf MP. Artificial niche microarrays for probing single stem cell fate in high throughput. Nat Methods 2011; 8(11): 949-955

61. Shih YR, Tseng KF, Lai HY, Lin CH, Lee OK. Matrix stiffness regulation of integrin-mediated mechanotransduction during osteogenic differentiation of human mesenchymal stem cells. J Bone Miner Res 2011; 26(4): 730-738

62. Hirata M, Yamaoka T. Effect of stem cell niche elasticity/ECM protein on the self-beating cardiomyocyte differentiation of induced pluripotent stem (iPS) cells at different stages. Acta Biomater 2018; 65: 44-52

63. Muncie JM, Ayad NME, Lakins JN, Xue X, Fu J, Weaver VM. Mechanical tension promotes formation of gastrulation-like nodes and patterns mesoderm specification in human embryonic stem cells. Dev Cell 2020; 55(6): 679-694.e11

64. Guo H, Deng N, Dou L, Ding H, Criswell T, Atala A, Furdui CM, Zhang Y. 3-D human renal tubular organoids generated from urinederived stem cells for nephrotoxicity screening. ACS Biomater Sci Eng 2020; 6(12): 6701-6709

65. Morrison SJ, Spradling AC. Stem cells and niches: mechanisms that promote stem cell maintenance throughout life. Cell 2008; 132(4): 598-611

66. Fuchs E, Tumbar T, Guasch G. Socializing with the neighbors: stem cells and their niche. Cell 2004; 116(6): 769-778

67. Badylak SF, Taylor D, Uygun K. Whole-organ tissue engineering: decellularization and recellularization of three-dimensional matrix scaffolds. Annu Rev Biomed Eng 2011; 13(1): 27-53

68. Ngangan AV, McDevitt TC. Acellularization of embryoid bodies via physical disruption methods. Biomaterials 2009; 30(6): 11431149

69. Hirata M, Yamaoka T. Hepatocytic differentiation of iPS cells on decellularized liver tissue. J Artif Organs 2017; 20(4): 318-325

70. Lu H, Hoshiba T, Kawazoe N, Chen G. Autologous extracellular matrix scaffolds for tissue engineering. Biomaterials 2011; 32(10): 2489-2499

71. Nair R, Shukla S, McDevitt TC. Acellular matrices derived from differentiating embryonic stem cells. J Biomed Mater Res A 2008; 87A(4): 1075-1085

72. Ott HC, Clippinger B, Conrad C, Schuetz C, Pomerantseva I, Ikonomou L, Kotton D, Vacanti JP. Regeneration and orthotopic transplantation of a bioartificial lung. Nat Med 2010; 16(8): 927933

73. Reing JE, Brown BN, Daly KA, Freund JM, Gilbert TW, Hsiong SX, Huber A, Kullas KE, Tottey S, Wolf MT, Badylak SF. The effects of processing methods upon mechanical and biologic properties of porcine dermal extracellular matrix scaffolds. Biomaterials 2010; 31(33): 8626-8633

74. Haas R, Culp LA. Binding of fibronectin to gelatin and heparin: effect of surface denaturation and detergents. FEBS Lett 1984; 174(2): 279-283

75. Sart S, Ma T, Li Y. Extracellular matrices decellularized from embryonic stem cells maintained their structure and signaling specificity. Tissue Eng Part A 2014; 20(1-2): 54-66
76. Crapo PM, Gilbert TW, Badylak SF. An overview of tissue and whole organ decellularization processes. Biomaterials 2011; 32(12): 3233-3243

77. Parmaksiz M, Elçin AE, Elçin YM. Decellularized cell culture ECMs act as cell differentiation inducers. Stem Cell Rev Rep 2020; 16(3): 569-584

78. Freytes DO, Stoner RM, Badylak SF. Uniaxial and biaxial properties of terminally sterilized porcine urinary bladder matrix scaffolds. J Biomed Mater Res B Appl Biomater 2008; 84B(2): 408-414

79. Yang B, Zhang Y, Zhou L, Sun Z, Zheng J, Chen Y, Dai Y. Development of a porcine bladder acellular matrix with wellpreserved extracellular bioactive factors for tissue engineering. Tissue Eng Part C Methods 2010; 16(5): 1201-1211

80. Gilbert TW, Sellaro TL, Badylak SF. Decellularization of tissues and organs. Biomaterials 2006; 27(19): 3675-3683

81. Gafarova ER, Grebenik EA, Lazhko AE, Frolova AA, Kuryanova AS, Kurkov AV, Bazhanov IA, Kapomba BS, Kosheleva NV, Novikov IA, Shekhter AB, Golubeva EN, Soloviova AB, Timashev PS. Evaluation of supercritical $\mathrm{CO}_{2}$-assisted protocols in a model of ovine aortic root decellularization. Molecules 2020; 25(17): 3923

82. Seddon AM, Curnow P, Booth PJ. Membrane proteins, lipids and detergents: not just a soap opera. Biochim Biophys Acta 2004; 1666(1-2): 105-117

83. Grauss RW, Hazekamp MG, van Vliet S, Gittenberger-de Groot AC, DeRuiter MC. Decellularization of rat aortic valve allografts reduces leaflet destruction and extracellular matrix remodeling. J Thorac Cardiovasc Surg 2003; 126(6): 2003-2010

84. Hopkinson A, Shanmuganathan VA, Gray T, Yeung AM, Lowe J, James DK, Dua HS. Optimization of amniotic membrane (AM) denuding for tissue engineering. Tissue Eng Part C Methods 2008; 14(4): 371-381

85. Petersen TH, Calle EA, Zhao L, Lee EJ, Gui L, Raredon MB, Gavrilov K, Yi T, Zhuang ZW, Breuer C, Herzog E, Niklason LE. Tissue-engineered lungs for in vivo implantation. Science 2010; 329(5991): 538-541

86. Gui L, Chan SA, Breuer CK, Niklason LE. Novel utilization of serum in tissue decellularization. Tissue Eng Part C Methods 2010; 16(2): 173-184

87. Zhang D, Zhang Y, Zhang Y, Yi H, Wang Z, Wu R, He D, Wei G, Wei S, Hu Y, Deng J, Criswell T, Yoo J, Zhou Y, Atala A. Tissuespecific extracellular matrix enhances skeletal muscle precursor cell expansion and differentiation for potential application in cell therapy. Tissue Eng Part A 2017; 23(15-16): 784-794

88. Yi H, Forsythe S, He Y, Liu Q, Xiong G, Wei S, Li G, Atala A, Skardal A, Zhang Y. Tissue-specific extracellular matrix promotes myogenic differentiation of human muscle progenitor cells on gelatin and heparin conjugated alginate hydrogels. Acta Biomater 2017; 62: 222-233

89. Buckenmeyer MJ, Meder TJ, Prest TA, Brown BN. Decellularization techniques and their applications for the repair and regeneration of the nervous system. Methods 2020; 171: 41-61

90. Crapo PM, Medberry CJ, Reing JE, Tottey S, van der Merwe Y, Jones KE, Badylak SF. Biologic scaffolds composed of central nervous system extracellular matrix. Biomaterials 2012; 33(13): $3539-3547$ 
91. Jiang T, Ren XJ, Tang JL, Yin H, Wang KJ, Zhou CL. Preparation and characterization of genipin-crosslinked rat acellular spinal cord scaffolds. Mater Sci Eng C 2013; 33(6): 3514-3521

92. Brown BN, Valentin JE, Stewart-Akers AM, McCabe GP, Badylak SF. Macrophage phenotype and remodeling outcomes in response to biologic scaffolds with and without a cellular component. Biomaterials 2009; 30(8): 1482-1491

93. Wainwright JM, Czajka CA, Patel UB, Freytes DO, Tobita K, Gilbert TW, Badylak SF. Preparation of cardiac extracellular matrix from an intact porcine heart. Tissue Eng Part C Methods 2010; 16(3): 525-532

94. Cortiella J, Niles J, Cantu A, Brettler A, Pham A, Vargas G, Winston S, Wang J, Walls S, Nichols JE. Influence of acellular natural lung matrix on murine embryonic stem cell differentiation and tissue formation. Tissue Eng Part A 2010; 16(8): 2565-2580

95. Prasertsung I, Kanokpanont S, Bunaprasert T, Thanakit V, Damrongsakkul S. Development of acellular dermis from porcine skin using periodic pressurized technique. J Biomed Mater Res B Appl Biomater 2008; 85B(1): 210-219

96. Montoya CV, McFetridge PS. Preparation of ex vivo-based biomaterials using convective flow decellularization. Tissue Eng Part C Methods 2009; 15(2): 191-200

97. Bolland F, Korossis S, Wilshaw SP, Ingham E, Fisher J, Kearney JN, Southgate J. Development and characterisation of a fullthickness acellular porcine bladder matrix for tissue engineering. Biomaterials 2007; 28(6): 1061-1070

98. Sano MB, Neal RE 2nd, Garcia PA, Gerber D, Robertson J, Davalos RV. Towards the creation of decellularized organ constructs using irreversible electroporation and active mechanical perfusion. Biomed Eng Online 2010; 9(1): 83

99. Phillips M, Maor E, Rubinsky B. Nonthermal irreversible electroporation for tissue decellularization. J Biomech Eng 2010; 132(9): 091003

100. Dong X, Wei X, Yi W, Gu C, Kang X, Liu Y, Li Q, Yi D. RGDmodified acellular bovine pericardium as a bioprosthetic scaffold for tissue engineering. J Mater Sci Mater Med 2009; 20(11): 23272336

101. Uygun BE, Soto-Gutierrez A, Yagi H, Izamis ML, Guzzardi MA, Shulman C, Milwid J, Kobayashi N, Tilles A, Berthiaume F, Hertl M, Nahmias Y, Yarmush ML, Uygun K. Organ reengineering through development of a transplantable recellularized liver graft using decellularized liver matrix. Nat Med 2010; 16(7): 814-820

102. Nakayama KH, Batchelder CA, Lee CI, Tarantal AF. Decellularized rhesus monkey kidney as a three-dimensional scaffold for renal tissue engineering. Tissue Eng Part A 2010; 16(7): 22072216

103. McFetridge PS, Daniel JW, Bodamyali T, Horrocks M, Chaudhuri JB. Preparation of porcine carotid arteries for vascular tissue engineering applications. J Biomed Mater Res A 2004; 70A(2): 224-234

104. Teebken OE, Bader A, Steinhoff G, Haverich A. Tissue engineering of vascular grafts: human cell seeding of decellularised porcine matrix. Eur J Vasc Endovasc Surg 2000; 19(4): 381-386

105. Gamba PG, Conconi MT, Lo Piccolo R, Zara G, Spinazzi R, Parnigotto PP. Experimental abdominal wall defect repaired with acellular matrix. Pediatr Surg Int 2002; 18(5-6): 327-331
106. Chen RN, Ho HO, Tsai YT, Sheu MT. Process development of an acellular dermal matrix (ADM) for biomedical applications. Biomaterials 2004; 25(13): 2679-2686

107. Rieder E, Kasimir MT, Silberhumer G, Seebacher G, Wolner E, Simon P, Weigel G. Decellularization protocols of porcine heart valves differ importantly in efficiency of cell removal and susceptibility of the matrix to recellularization with human vascular cells. J Thorac Cardiovasc Surg 2004; 127(2): 399-405

108. Dahl SLM, Koh J, Prabhakar V, Niklason LE. Decellularized native and engineered arterial scaffolds for transplantation. Cell Transplant 2003; 12(6): 659-666

109. Woods T, Gratzer PF. Effectiveness of three extraction techniques in the development of a decellularized bone-anterior cruciate ligament-bone graft. Biomaterials 2005; 26(35): 7339-7349

110. Shakouri-Motlagh A, O’Connor AJ, Brennecke SP, Kalionis B, Heath DE. Native and solubilized decellularized extracellular matrix: a critical assessment of their potential for improving the expansion of mesenchymal stem cells. Acta Biomater 2017; 55: 112

111. Assunção M, Dehghan-Baniani D, Yiu CHK, Später T, Beyer S, Blocki A. Cell-derived extracellular matrix for tissue engineering and regenerative medicine. Front Bioeng Biotechnol 2020; 8: 602009

112. Pei M, Li JT, Shoukry M, Zhang Y. A review of decellularized stem cell matrix: a novel cell expansion system for cartilage tissue engineering. Eur Cell Mater 2011; 22: 333-343

113. Pei M. Environmental preconditioning rejuvenates adult stem cells' proliferation and chondrogenic potential. Biomaterials 2017; 117: $10-23$

114. Sun Y, Yan L, Chen S, Pei M. Functionality of decellularized matrix in cartilage regeneration: a comparison of tissue versus cell sources. Acta Biomater 2018; 74: 56-73

115. He F, Chen X, Pei M. Reconstruction of an in vitro tissue-specific microenvironment to rejuvenate synovium-derived stem cells for cartilage tissue engineering. Tissue Eng Part A 2009; 15(12): 3809-3821

116. Li J, Pei M. Optimization of an in vitro three-dimensional microenvironment to reprogram synovium-derived stem cells for cartilage tissue engineering. Tissue Eng Part A 2011; 17(5-6): 703-712

117. Li J, He F, Pei M. Creation of an in vitro microenvironment to enhance human fetal synovium-derived stem cell chondrogenesis. Cell Tissue Res 2011; 345(3): 357-365

118. Li J, He F, Pei M. Chondrogenic priming of human fetal synoviumderived stem cells in an adult stem cell matrix microenvironment. Genes Dis 2015; 2(4): 337-346

119. Li J, Narayanan K, Zhang Y, Hill RC, He F, Hansen KC, Pei M. Role of lineage-specific matrix in stem cell chondrogenesis. Biomaterials 2020; 231: 119681

120. Pei M, Zhang Y, Li J, Chen D. Antioxidation of decellularized stem cell matrix promotes human synovium-derived stem cellbased chondrogenesis. Stem Cells Dev 2013; 22(6): 889-900

121. Zhang Y, Li J, Davis ME, Pei M. Delineation of in vitro chondrogenesis of human synovial stem cells following preconditioning using decellularized matrix. Acta Biomater 2015; 20: 3950

122. Zhang Y, Pizzute T, Li J, He F, Pei M. sb203580 preconditioning 
recharges matrix-expanded human adult stem cells for chondrogenesis in an inflammatory environment - a feasible approach for autologous stem cell based osteoarthritic cartilage repair. Biomaterials 2015; 64: 88-97

123. He F, Liu X, Xiong K, Chen S, Zhou L, Cui W, Pan G, Luo ZP, Pei M, Gong Y. Extracellular matrix modulates the biological effects of melatonin in mesenchymal stem cells. J Endocrinol 2014; 223(2): 167-180

124. Pei M, He F, Kish VL. Expansion on extracellular matrix deposited by human bone marrow stromal cells facilitates stem cell proliferation and tissue-specific lineage potential. Tissue Eng Part A 2011; 17(23-24): 3067-3076

125. Pei M, Li J, Zhang Y, Liu G, Wei L, Zhang Y. Expansion on a matrix deposited by nonchondrogenic urine stem cells strengthens the chondrogenic capacity of repeated-passage bone marrow stromal cells. Cell Tissue Res 2014; 356(2): 391-403

126. Liu X, Zhou L, Chen X, Liu T, Pan G, Cui W, Li M, Luo ZP, Pei M, Yang H, Gong Y, He F. Culturing on decellularized extracellular matrix enhances antioxidant properties of human umbilical cord-derived mesenchymal stem cells. Mater Sci Eng C 2016; 61: 437-448

127. Zhou L, Chen X, Liu T, Zhu C, Si M, Jargstorf J, Li M, Pan G, Gong Y, Luo ZP, Yang H, Pei M, He F. SIRT1-dependent antisenescence effects of cell-deposited matrix on human umbilical cord mesenchymal stem cells. J Tissue Eng Regen Med 2018; 12(2): e1008-e1021

128. He F, Pei M. Extracellular matrix enhances differentiation of adipose stem cells from infrapatellar fat pad toward chondrogenesis. J Tissue Eng Regen Med 2013; 7(1): 73-84

129. Wang Y, Fu Y, Yan Z, Zhang XB, Pei M. Impact of fibronectin knockout on proliferation and differentiation of human infrapatellar fat pad-derived stem cells. Front Bioeng Biotechnol 2019; 7: 321

130. Wang Y, Hu G, Hill RC, Dzieciatkowska M, Hansen KC, Zhang XB, Yan Z, Pei M. Matrix reverses immortalization-mediated stem cell fate determination. Biomaterials 2021; 265: 120387

131. Goh SK, Olsen P, Banerjee I. Extracellular matrix aggregates from differentiating embryoid bodies as a scaffold to support ESC proliferation and differentiation. PLoS One 2013; 8(4): e61856

132. Xiong X, Yang X, Dai H, Feng G, Zhang Y, Zhou J, Zhou W. Extracellular matrix derived from human urine-derived stem cells enhances the expansion, adhesion, spreading, and differentiation of human periodontal ligament stem cells. Stem Cell Res Ther 2019; 10(1): 396

133. Hoshiba T, Sugano Y, Yokoyama N. Murine neural stem cell (NSC) line, MEB5-derived decellularized matrix as an in vitro extracellular matrix model in NSC niche. Chem Lett 2018; 47(12): 1498-1501

134. Pei M, He F. Extracellular matrix deposited by synovium-derived stem cells delays replicative senescent chondrocyte dedifferentiation and enhances redifferentiation. J Cell Physiol 2012; 227(5): 2163-2174

135. Yan J, Chen X, Pu C, Zhao Y, Liu X, Liu T, Pan G, Lin J, Pei M, Yang H, He F. Synovium stem cell-derived matrix enhances antiinflammatory properties of rabbit articular chondrocytes via the SIRT1 pathway. Mater Sci Eng C 2020; 106: 110286

136. He F, Pei M. Rejuvenation of nucleus pulposus cells using extracellular matrix deposited by synovium-derived stem cells. Spine 2012; 37(6): 459-469

137. Pei M, Shoukry M, Li J, Daffner SD, France JC, Emery SE. Modulation of in vitro microenvironment facilitates synoviumderived stem cell-based nucleus pulposus tissue regeneration. Spine 2012; 37(18): 1538-1547

138. Kanninen LK, Porola P, Niklander J, Malinen MM, Corlu A, Guguen-Guillouzo C, Urtti A, Yliperttula ML, Lou YR. Hepatic differentiation of human pluripotent stem cells on human liver progenitor HepaRG-derived acellular matrix. Exp Cell Res 2016; 341(2): 207-217

139. Pei M, He F, Li J, Tidwell JE, Jones AC, McDonough EB. Repair of large animal partial-thickness cartilage defects through intraarticular injection of matrix-rejuvenated synovium-derived stem cells. Tissue Eng Part A 2013; 19(9-10): 1144-1154

140. Li J, Hansen KC, Zhang Y, Dong C, Dinu CZ, Dzieciatkowska M, Pei M. Rejuvenation of chondrogenic potential in a young stem cell microenvironment. Biomaterials 2014; 35(2): 642-653

141. Ng CP, Sharif AR, Heath DE, Chow JW, Zhang CB, Chan-Park $\mathrm{MB}$, Hammond PT, Chan JK, Griffith LG. Enhanced ex vivo expansion of adult mesenchymal stem cells by fetal mesenchymal stem cell ECM. Biomaterials 2014; 35(13): 4046-4057

142. Xu Y, Xu GY, Tang C, Wei B, Pei X, Gui JC, Min BH, Jin CZ, Wang LM. Preparation and characterization of bone marrow mesenchymal stem cell-derived extracellular matrix scaffolds. J Biomed Mater Res B Appl Biomater 2015; 103(3): 670-678

143. Chen XD, Dusevich V, Feng JQ, Manolagas SC, Jilka RL. Extracellular matrix made by bone marrow cells facilitates expansion of marrow-derived mesenchymal progenitor cells and prevents their differentiation into osteoblasts. J Bone Miner Res 2007; 22(12): 1943-1956

144. Lai Y, Sun Y, Skinner CM, Son EL, Lu Z, Tuan RS, Jilka RL, Ling $\mathrm{J}$, Chen XD. Reconstitution of marrow-derived extracellular matrix ex vivo: a robust culture system for expanding large-scale highly functional human mesenchymal stem cells. Stem Cells Dev 2010; 19(7): 1095-1107

145. Gu Y, Zhu J, Xue C, Li Z, Ding F, Yang Y, Gu X. Chitosan/silk fibroin-based, Schwann cell-derived extracellular matrix-modified scaffolds for bridging rat sciatic nerve gaps. Biomaterials 2014; 35(7): 2253-2263

146. Kwon SH, Lee TJ, Park J, Hwang JE, Jin M, Jang HK, Hwang NS, Kim BS. Modulation of BMP-2-induced chondrogenic versus osteogenic differentiation of human mesenchymal stem cells by cell-specific extracellular matrices. Tissue Eng Part A 2013; 19(1-2): 49-58

147. Zhang Y, He Y, Bharadwaj S, Hammam N, Carnagey K, Myers R, Atala A, Van Dyke M. Tissue-specific extracellular matrix coatings for the promotion of cell proliferation and maintenance of cell phenotype. Biomaterials 2009; 30(23-24): 4021-4028

148. Thibault RA, Scott Baggett L, Mikos AG, Kasper FK. Osteogenic differentiation of mesenchymal stem cells on pregenerated extracellular matrix scaffolds in the absence of osteogenic cell culture supplements. Tissue Eng Part A 2010; 16(2): 431-440

149. De Waele J, Reekmans K, Daans J, Goossens H, Berneman Z, Ponsaerts P. 3D culture of murine neural stem cells on decellularized mouse brain sections. Biomaterials 2015; 41: 122131 
150. Navarro-Tableros V, Herrera Sanchez MB, Figliolini F, Romagnoli R, Tetta C, Camussi G. Recellularization of rat liver scaffolds by human liver stem cells. Tissue Eng Part A 2015; 21(11-12): 19291939

151. Yao Q, Zheng YW, Lan QH, Kou L, Xu HL, Zhao YZ. Recent development and biomedical applications of decellularized extracellular matrix biomaterials. Mater Sci Eng C 2019; 104: 109942

152. Imle A, Kumberger $P$, Schnellbächer ND, Fehr J, CarrilloBustamante P, Ales J, Schmidt P, Ritter C, Godinez WJ, Müller B, Rohr K, Hamprecht FA, Schwarz US, Graw F, Fackler OT. Experimental and computational analyses reveal that environmental restrictions shape HIV-1 spread in 3D cultures. Nat Commun 2019; 10(1): 2144

153. Saldin LT, Cramer MC, Velankar SS, White LJ, Badylak SF. Extracellular matrix hydrogels from decellularized tissues: Structure and function. Acta Biomater 2017; 49: 1-15

154. González-Díaz EC, Varghese S. Hydrogels as extracellular matrix analogs. Gels 2016; 2(3): 20

155. Zhang Y, He Y, Bharadwaj S, Hammam N, Carnagey K, Myers R, Atala A, Van Dyke M. Tissue-specific extracellular matrix coatings for the promotion of cell proliferation and maintenance of cell phenotype. Biomaterials 2009; 30(23-24): 4021-4028

156. Yi H, S. F, Zhang Y, Skardal A. Bio-functionalized alginate hydrogels for improved cell-matrix interactions and growth factor sequestration kinetics. Tissue Eng Part A 2015; 21(Suppl 1): S187

157. Skardal A, Smith L, Bharadwaj S, Atala A, Soker S, Zhang Y. Tissue specific synthetic ECM hydrogels for 3-D in vitro maintenance of hepatocyte function. Biomaterials 2012; 33(18): $4565-4575$

158. Lang R, Stern MM, Smith L, Liu Y, Bharadwaj S, Liu G, Baptista PM, Bergman CR, Soker S, Yoo JJ, Atala A, Zhang Y. Threedimensional culture of hepatocytes on porcine liver tissue-derived extracellular matrix. Biomaterials 2011; 32(29): 7042-7052

159. Xiong G, Tang W, Zhang D, He D, Wei G, Atala A, Liang XJ, Bleyer AJ, Bleyer ME, Yu J, Aloi JA, Ma JX, Furdui CM, Zhang Y. Impaired regeneration potential in urinary stem cells diagnosed from the patients with diabetic nephropathy. Theranostics 2019; 9(14): 4221-4232

160. Hussey GS, Dziki JL, Badylak SF. Extracellular matrix-based materials for regenerative medicine. Nat Rev Mater 2018; 3(7): $159-173$

161. Juhasz I, Kiss B, Lukacs L, Erdei I, Peter Z, Remenyik E. Longterm followup of dermal substitution with acellular dermal implant in burns and postburn scar corrections. Dermatol Res Pract 2010; 2010(1): 210150

162. Landsman AS, Cook J, Cook E, Landsman AR, Garrett P, Yoon J, Kirkwood A, Desman E. A retrospective clinical study of 188 consecutive patients to examine the effectiveness of a biologically active cryopreserved human skin allograft (TheraSkin $\left.{ }^{\circledR}\right)$ on the treatment of diabetic foot ulcers and venous leg ulcers. Foot Ankle Spec 2011; 4(1): 29-41

163. Wainwright DJ. Use of an acellular allograft dermal matrix (AlloDerm) in the management of full-thickness burns. Burns 1995; 21(4): 243-248

164. Yoeruek E, Bayyoud T, Maurus C, Hofmann J, Spitzer MS, BartzSchmidt KU, Szurman P. Reconstruction of corneal stroma with decellularized porcine xenografts in a rabbit model. Acta
Ophthalmol 2012; 90(3): e206-e210

165. Hashimoto Y, Hattori S, Sasaki S, Honda T, Kimura T, Funamoto S, Kobayashi H, Kishida A. Ultrastructural analysis of the decellularized cornea after interlamellar keratoplasty and microkeratome-assisted anterior lamellar keratoplasty in a rabbit model. Sci Rep 2016; 6(1): 27734

166. Liu Y, Ma W, Liu B, Wang Y, Chu J, Xiong G, Shen L, Long C, Lin T, He D, Butnaru D, Alexey L, Zhang Y, Zhang D, Wei G. Urethral reconstruction with autologous urine-derived stem cells seeded in three-dimensional porous small intestinal submucosa in a rabbit model. Stem Cell Res Ther 2017; 8(1): 63

167. Zhang Y, Liu G, Kropp BP. Re-epithelialization of demucosalized stomach patch with tissue-engineered urothelial mucosa combined with Botox A in bladder augmentation. BJU Int 2012; 110(2b): E106-E112

168. Zhang Y, Lin HK, Frimberger D, Epstein RB, Kropp BP. Growth of bone marrow stromal cells on small intestinal submucosa: an alternative cell source for tissue engineered bladder. BJU Int 2005; 96(7): 1120-1125

169. Nherera LM, Romanelli M, Trueman P, Dini V. An overview of clinical and health economic evidence regarding porcine small intestine submucosa extracellular matrix in the management of chronic wounds and burns. Ostomy Wound Manage 2017; 63(12): $38-47$

170. Hashimoto Y, Funamoto S, Sasaki S, Honda T, Hattori S, Nam K, Kimura T, Mochizuki M, Fujisato T, Kobayashi H, Kishida A. Preparation and characterization of decellularized cornea using high-hydrostatic pressurization for corneal tissue engineering. Biomaterials 2010; 31(14): 3941-3948

171. Matsumoto T, Holmes RHO, Burdick CO, Heisterkamp CA 3rd, O'Connell TJ Jr. Replacement of large veins with free inverted segments of small bowel: autografts of submucosal membrane in dogs and clinical use. Ann Surg 1966; 164(5): 845-848

172. Matsumoto T, Holmes RH, Burdick CO, Heisterkamp CA 3rd, O'Connell TJ Jr. The fate of the inverted segment of small bowel used for the replacement of major veins. Surgery 1966; 60(3): 739743

173. Matsumoto T, Holmes RH, Burdick CO, Metzger JF, Heisterkamp CA 3rd, O'Connell TJ Jr. A study of inverted intestinal graft in the major veins. Angiology 1966; 17(11): 842-850

174. Badylak SF, Lantz GC, Coffey A, Geddes LA. Small intestinal submucosa as a large diameter vascular graft in the dog. J Surg Res 1989; 47(1): 74-80

175. Hiles MC, Badylak SF, Lantz GC, Kokini K, Geddes LA, Morff RJ. Mechanical properties of xenogeneic small-intestinal submucosa when used as an aortic graft in the dog. J Biomed Mater Res 1995; 29(7): 883-891

176. Bader A, Steinhoff G, Strobl K, Schilling T, Brandes G, Mertsching H, Tsikas D, Froelich J, Haverich A. Engineering of human vascular aortic tissue based on a xenogeneic starter matrix. Transplantation 2000; 70(1): 7-14

177. Taylor DA, Sampaio LC, Ferdous Z, Gobin AS, Taite LJ. Decellularized matrices in regenerative medicine. Acta Biomater 2018; 74: 74-89

178. Kimicata M, Allbritton-King JD, Navarro J, Santoro M, Inoue T, Hibino N, Fisher JP. Assessment of decellularized pericardial extracellular matrix and poly(propylene fumarate) biohybrid for 
small-diameter vascular graft applications. Acta Biomater 2020; 110: 68-81

179. Badylak S, Meurling S, Chen M, Spievack A, Simmons-Byrd A. Resorbable bioscaffold for esophageal repair in a dog model. J Pediatr Surg 2000; 35(7): 1097-1103

180. Badylak SF, Hoppo T, Nieponice A, Gilbert TW, Davison JM, Jobe BA. Esophageal preservation in five male patients after endoscopic inner-layer circumferential resection in the setting of superficial cancer: a regenerative medicine approach with a biologic scaffold. Tissue Eng Part A 2011; 17(11-12): 1643-1650

181. Clough A, Ball J, Smith GS, Leibman S. Porcine small intestine submucosa matrix (Surgisis) for esophageal perforation. Ann Thorac Surg 2011; 91(2): e99-e100

182. Syed O, Walters NJ, Day RM, Kim HW, Knowles JC. Evaluation of decellularization protocols for production of tubular small intestine submucosa scaffolds for use in oesophageal tissue engineering. Acta Biomater 2014; 10(12): 5043-5054

183. Luc G, Charles G, Gronnier C, Cabau M, Kalisky C, Meulle M, Bareille R, Roques S, Couraud L, Rannou J, Bordenave L, Collet D, Durand M. Decellularized and matured esophageal scaffold for circumferential esophagus replacement: proof of concept in a pig model. Biomaterials 2018; 175: 1-18

184. Arakelian L, Caille C, Faivre L, Corté L, Bruneval P, Shamdani S, Flageollet C, Albanese P, Domet T, Jarraya M, Setterblad N, Kellouche S, Larghero J, Cattan P, Vanneaux V. A clinical-grade acellular matrix for esophageal replacement. J Tissue Eng Regen Med 2019; 13(12): 2191-2203

185. Zhang Y, Frimberger D, Cheng EY, Lin HK, Kropp BP. Challenges in a larger bladder replacement with cell-seeded and unseeded small intestinal submucosa grafts in a subtotal cystectomy model. BJU Int 2006; 98(5): 1100-1105

186. Kropp BP, Eppley BL, Prevel CD, Rippy MK, Harruff RC, Badylak SF, Adams MC, Rink RC, Keating MA. Experimental assessment of small intestinal submucosa as a bladder wall substitute. Urology 1995; 46(3): 396-400

187. Zhang XZ, Jiang YL, Hu JG, Zhao LM, Chen QZ, Liang Y, Zhang Y, Lei XX, Wang R, Lei Y, Zhang QY, Li-Ling J, Xie HQ. Procyanidins-crosslinked small intestine submucosa: a bladder patch promotes smooth muscle regeneration and bladder function restoration in a rabbit model. Bioact Mater 2021; 6(6): 1827-1838

188. Kropp BP, Ludlow JK, Spicer D, Rippy MK, Badylak SF, Adams MC, Keating MA, Rink RC, Birhle R, Thor KB. Rabbit urethral regeneration using small intestinal submucosa onlay grafts. Urology 1998; 52(1): 138-142

189. Davis NF, Callanan A, McGuire BB, Flood HD, McGloughlin TM. Evaluation of viability and proliferative activity of human urothelial cells cultured onto xenogenic tissue-engineered extracellular matrices. Urology 2011; 77(4): 1007.e1-1007.e7

190. Janke HP, de Jonge PKJD, Feitz WFJ, Oosterwijk E. Reconstruction strategies of the ureter and urinary diversion using tissue engineering approaches. Tissue Eng Part B Rev 2019; 25(3): 237248

191. Adamowicz J, Van Breda SV, Kloskowski T, Juszczak K, Pokrywczynska M, Drewa T. Constructing artificial urinary conduits: current capabilities and future potential. Expert Rev Med Devices 2019; 16(2): 135-144

192. Totonelli G, Maghsoudlou P, Garriboli M, Riegler J, Orlando G,
Burns AJ, Sebire NJ, Smith VV, Fishman JM, Ghionzoli M, Turmaine M, Birchall MA, Atala A, Soker S, Lythgoe MF, Seifalian A, Pierro A, Eaton S, De Coppi P. A rat decellularized small bowel scaffold that preserves villus-crypt architecture for intestinal regeneration. Biomaterials 2012; 33(12): 3401-3410

193. Arunkalaivanan AS, Barrington JW. Randomized trial of porcine dermal sling (Pelvicol implant) vs. tension-free vaginal tape (TVT) in the surgical treatment of stress incontinence: a questionnairebased study. Int Urogynecol J Pelvic Floor Dysfunct 2003; 14(1): $17-23$

194. Andrée B, Bär A, Haverich A, Hilfiker A. Small intestinal submucosa segments as matrix for tissue engineering: review. Tissue Eng Part B Rev 2013; 19(4): 279-291

195. Roeder RA, Lantz GC, Geddes LA. Mechanical remodeling of small-intestine submucosa small-diameter vascular grafts-a preliminary report. Biomed Instrum Technol 2001; 35(2): 110-120

196. Ott HC, Matthiesen TS, Goh SK, Black LD, Kren SM, Netoff TI, Taylor DA. Perfusion-decellularized matrix: using nature's platform to engineer a bioartificial heart. Nat Med 2008; 14(2): 213221

197. Mecham RP. Overview of extracellular matrix. Current Protocols in Cell Biology 2012; Chapter 10: Unit 10.11

198. Plunkett N, O'Brien FJ. Bioreactors in tissue engineering. Technol Health Care 2011; 19(1): 55-69

199. Scarritt ME, Pashos NC, Bunnell BA. A review of cellularization strategies for tissue engineering of whole organs. Front Bioeng Biotechnol 2015; 3: 43

200. Nari GA, Mariana C, Romina C, Laura R, Gustavo J, Ricardo T, Salvatierra NA. Preparation of a three-dimensional extracellular matrix by decellularization of rabbit livers. Rev Esp Enferm Dig 2013; 105(3): 138-143

201. Baptista PM, Siddiqui MM, Lozier G, Rodriguez SR, Atala A, Soker S. The use of whole organ decellularization for the generation of a vascularized liver organoid. Hepatology 2011; 53(2): 604-617

202. Wang Y, Cui CB, Yamauchi M, Miguez P, Roach M, Malavarca R, Costello MJ, Cardinale V, Wauthier E, Barbier C, Gerber DA, Alvaro D, Reid LM. Lineage restriction of human hepatic stem cells to mature fates is made efficient by tissue-specific biomatrix scaffolds. Hepatology 2011; 53(1): 293-305

203. Soto-Gutierrez A, Zhang L, Medberry C, Fukumitsu K, Faulk D, Jiang H, Reing J, Gramignoli R, Komori J, Ross M, Nagaya M, Lagasse E, Stolz D, Strom SC, Fox IJ, Badylak SF. A whole-organ regenerative medicine approach for liver replacement. Tissue Eng Part C Methods 2011; 17(6): 677-686

204. Mazza G, Rombouts K, Rennie Hall A, Urbani L, Vinh Luong T, Al-Akkad W, Longato L, Brown D, Maghsoudlou P, Dhillon AP, Fuller B, Davidson B, Moore K, Dhar D, De Coppi P, Malago M, Pinzani M. Decellularized human liver as a natural 3D-scaffold for liver bioengineering and transplantation. Sci Rep 2015; 5(1): 13079

205. Verstegen MMA, Willemse J, van den Hoek S, Kremers GJ, Luider TM, van Huizen NA, Willemssen FEJA, Metselaar HJ, IJzermans JNM, van der Laan LJW, de Jonge J. Decellularization of whole human liver grafts using controlled perfusion for transplantable organ bioscaffolds. Stem Cells Dev 2017; 26(18): 1304-1315

206. Song JJ, Kim SS, Liu Z, Madsen JC, Mathisen DJ, Vacanti JP, Ott 
HC. Enhanced in vivo function of bioartificial lungs in rats. Ann Thorac Surg 2011; 92(3): 998-1006

207. Petersen TH, Calle EA, Colehour MB, Niklason LE. Bioreactor for the long-term culture of lung tissue. Cell Transplant 2011; 20(7): $1117-1126$

208. Zhou H, Kitano K, Ren X, Rajab TK, Wu M, Gilpin SE, Wu T, Baugh L, Black LD, Mathisen DJ, Ott HC. Bioengineering human lung grafts on porcine matrix. Ann Surg 2018; 267(3): 590-598

209. Zambon JP, Ko IK, Abolbashari M, Huling J, Clouse C, Kim TH, Smith C, Atala A, Yoo JJ. Comparative analysis of two porcine kidney decellularization methods for maintenance of functional vascular architectures. Acta Biomater 2018; 75: 226-234

210. Song JJ, Guyette JP, Gilpin SE, Gonzalez G, Vacanti JP, Ott HC. Regeneration and experimental orthotopic transplantation of a bioengineered kidney. Nat Med 2013; 19(5): 646-651

211. Mandrycky C, Phong K, Zheng Y. Tissue engineering toward organ-specific regeneration and disease modeling. MRS Commun 2017; 7(3): 332-347

212. Tsuji K, Bandyopadhyay A, Harfe BD, Cox K, Kakar S, Gerstenfeld L, Einhorn T, Tabin CJ, Rosen V. BMP2 activity, although dispensable for bone formation, is required for the initiation of fracture healing. Nat Genet 2006; 38(12): 1424-1429

213. Tsuji K, Cox K, Bandyopadhyay A, Harfe BD, Tabin CJ, Rosen V. BMP4 is dispensable for skeletogenesis and fracture-healing in the limb. J Bone Joint Surg Am 2008; 90(Suppl 1): 14-18

214. Tsuji K, Cox K, Gamer L, Graf D, Economides A, Rosen V. Conditional deletion of BMP7 from the limb skeleton does not affect bone formation or fracture repair. J Orthop Res 2010; 28(3): 384-389

215. Minear S, Leucht P, Jiang J, Liu B, Zeng A, Fuerer C, Nusse R, Helms JA. Wnt proteins promote bone regeneration. Sci Transl Med 2010; 2(29): 29ra30

216. Kakar S, Einhorn TA, Vora S, Miara LJ, Hon G, Wigner NA, Toben D, Jacobsen KA, Al-Sebaei MO, Song M, Trackman PC, Morgan EF, Gerstenfeld LC, Barnes GL. Enhanced chondrogenesis and Wnt signaling in PTH-treated fractures. J Bone Miner Res 2007; 22 (12): 1903-1912

217. Saidak Z, Le Henaff C, Azzi S, Marty C, Da Nascimento S, Sonnet $\mathrm{P}$, Marie PJ. Wnt/ $\beta$-catenin signaling mediates osteoblast differentiation triggered by peptide-induced $\alpha 5 \beta 1$ integrin priming in mesenchymal skeletal cells. J Biol Chem 2015; 290(11): 69036912

218. Zhu F, Sweetwyne MT, Hankenson KD. PKC $\delta$ is required for Jagged-1 induction of human mesenchymal stem cell osteogenic differentiation. Stem Cells 2013; 31(6): 1181-1192

219. Dishowitz MI, Zhu F, Sundararaghavan HG, Ifkovits JL, Burdick JA, Hankenson KD. Jagged1 immobilization to an osteoconductive polymer activates the Notch signaling pathway and induces osteogenesis. J Biomed Mater Res A 2014; 102(5): 1558-1567

220. Tian Y, Xu Y, Xue T, Chen L, Shi B, Shu B, Xie C, Max Morandi M, Jaeblon T, Marymont JV, Dong Y. Notch activation enhances mesenchymal stem cell sheet osteogenic potential by inhibition of cellular senescence. Cell Death Dis 2017; 8(2): e2595

221. Day TF, Guo X, Garrett-Beal L, Yang Y. Wnt/ $\beta$-catenin signaling in mesenchymal progenitors controls osteoblast and chondrocyte differentiation during vertebrate skeletogenesis. Dev Cell 2005; 8(5): 739-750
222. Ryu JH, Kim SJ, Kim SH, Oh CD, Hwang SG, Chun CH, Oh SH, Seong JK, Huh TL, Chun JS. Regulation of the chondrocyte phenotype by beta-catenin. Development 2002; 129(23): 55415550

223. Chaly Y, Blair HC, Smith SM, Bushnell DS, Marinov AD, Campfield BT, Hirsch R. Follistatin-like protein 1 regulates chondrocyte proliferation and chondrogenic differentiation of mesenchymal stem cells. Ann Rheum Dis 2015; 74(7): 1467-1473

224. Delhon L, Mahaut C, Goudin N, Gaudas E, Piquand K, Le Goff W, Cormier-Daire V, Le Goff C. Impairment of chondrogenesis and microfibrillar network in Adamts12 deficiency. FASEB J 2019; 33(2): 2707-2718

225. Fischer J, Knoch N, Sims T, Rosshirt N, Richter W. Timedependent contribution of BMP, FGF, IGF, and HH signaling to the proliferation of mesenchymal stroma cells during chondrogenesis. J Cell Physiol 2018; 233(11): 8962-8970

226. Murphy MK, Huey DJ, Hu JC, Athanasiou KA. TGF- $\beta 1$, GDF-5, and BMP-2 stimulation induces chondrogenesis in expanded human articular chondrocytes and marrow-derived stromal cells. Stem Cells 2015; 33(3): 762-773

227. Kovermann NJ, Basoli V, Della Bella E, Alini M, Lischer C, Schmal H, Kubosch EJ, Stoddart MJ. BMP2 and TGF- $\beta$ cooperate differently during synovial-derived stem-cell chondrogenesis in a dexamethasone-dependent manner. Cells 2019; 8(6): 636

228. Chung UI, Schipani E, McMahon AP, Kronenberg HM. Indian hedgehog couples chondrogenesis to osteogenesis in endochondral bone development. J Clin Invest 2001; 107(3): 295-304

229. Chen L, Liu G, Li W, Wu X. Chondrogenic differentiation of bone marrow-derived mesenchymal stem cells following transfection with Indian hedgehog and sonic hedgehog using a rotary cell culture system. Cell Mol Biol Lett 2019; 24(1): 16

230. Parisi A, Lacour F, Giordani L, Colnot S, Maire P, Le Grand F. APC is required for muscle stem cell proliferation and skeletal muscle tissue repair. J Cell Biol 2015; 210(5): 717-726

231. Zhang K, Zhang Y, Gu L, Lan M, Liu C, Wang M, Su Y, Ge M, Wang T, Yu Y, Liu C, Li L, Li Q, Zhao Y, Yu Z, Wang F, Li N, Meng Q. Islr regulates canonical Wnt signaling-mediated skeletal muscle regeneration by stabilizing Dishevelled-2 and preventing autophagy. Nat Commun 2018; 9(1): 5129

232. Rochat A, Fernandez A, Vandromme M, Molès JP, Bouschet T, Carnac G, Lamb NJ. Insulin and wnt1 pathways cooperate to induce reserve cell activation in differentiation and myotube hypertrophy. Mol Biol Cell 2004; 15(10): 4544-4555

233. Baghdadi MB, Castel D, Machado L, Fukada SI, Birk DE, Relaix F, Tajbakhsh S, Mourikis P. Reciprocal signalling by NotchCollagen V-CALCR retains muscle stem cells in their niche. Nature 2018; 557(7707): 714-718

234. Pisconti A, Cornelison DD, Olguín HC, Antwine TL, Olwin BB. Syndecan-3 and Notch cooperate in regulating adult myogenesis. J Cell Biol 2010; 190(3): 427-441

235. Pollen AA, Bhaduri A, Andrews MG, Nowakowski TJ, Meyerson OS, Mostajo-Radji MA, Di Lullo E, Alvarado B, Bedolli M, Dougherty ML, Fiddes IT, Kronenberg ZN, Shuga J, Leyrat AA, West JA, Bershteyn M, Lowe CB, Pavlovic BJ, Salama SR, Haussler D, Eichler EE, Kriegstein AR. Establishing cerebral organoids as models of human-specific brain evolution. Cell 2019; 176(4): 743-756.e17 
236. Fiddes IT, Lodewijk GA, Mooring M, Bosworth CM, Ewing AD, Mantalas GL, Novak AM, van den Bout A, Bishara A, Rosenkrantz JL, Lorig-Roach R, Field AR, Haeussler M, Russo L, Bhaduri A, Nowakowski TJ, Pollen AA, Dougherty ML, Nuttle X, Addor MC, Zwolinski S, Katzman S, Kriegstein A, Eichler EE, Salama SR, Jacobs FMJ, Haussler D. Human-specific NOTCH2NL genes affect notch signaling and cortical neurogenesis. Cell 2018; 173(6): 1356-1369.e22

237. Andersen J, Revah O, Miura Y, Thom N, Amin ND, Kelley KW, Singh M, Chen X, Thete MV, Walczak EM, Vogel H, Fan HC, Paşca SP. Generation of functional human 3D cortico-motor assembloids. Cell 2020;183(7):1913-1929.e1926

238. Gouti M, Tsakiridis A, Wymeersch FJ, Huang Y, Kleinjung J, Wilson V, Briscoe J. In vitro generation of neuromesodermal progenitors reveals distinct roles for wnt signalling in the specification of spinal cord and paraxial mesoderm identity. PLoS Biol 2014; 12(8): e1001937

239. Rivetti di Val Cervo P, Romanov RA, Spigolon G, Masini D, Martín-Montañez E, Toledo EM, La Manno G, Feyder M, Pifl C, $\mathrm{Ng} \mathrm{YH}$, Sánchez SP, Linnarsson S, Wernig M, Harkany T, Fisone $\mathrm{G}$, Arenas E. Induction of functional dopamine neurons from human astrocytes in vitro and mouse astrocytes in a Parkinson's disease model. Nat Biotechnol 2017; 35(5): 444-452

240. Ma JJ, Ju X, Xu RJ, Wang WH, Luo ZP, Liu CM, Yang L, Li B, Chen JQ, Meng B, Yang HL, Zhou FQ, Saijilafu. Telomerase reverse transcriptase and p53 regulate mammalian peripheral nervous system and CNS axon regeneration downstream of c-Myc. J Neurosci 2019; 39(46): 9107-9118

241. Mills RJ, Titmarsh DM, Koenig X, Parker BL, Ryall JG, QuaifeRyan GA, Voges HK, Hodson MP, Ferguson C, Drowley L, Plowright AT, Needham EJ, Wang QD, Gregorevic P, Xin M, Thomas WG, Parton RG, Nielsen LK, Launikonis BS, James DE, Elliott DA, Porrello ER, Hudson JE. Functional screening in human cardiac organoids reveals a metabolic mechanism for cardiomyocyte cell cycle arrest. Proc Natl Acad Sci USA 2017; 114(40): E8372-E8381

242. Titmarsh DM, Glass NR, Mills RJ, Hidalgo A, Wolvetang EJ, Porrello ER, Hudson JE, Cooper-White JJ. Induction of human iPSC-derived cardiomyocyte proliferation revealed by combinatorial screening in high density microbioreactor arrays. Sci Rep 2016; 6(1): 24637

243. Drakhlis L, Biswanath S, Farr CM, Lupanow V, Teske J, Ritzenhoff K, Franke A, Manstein F, Bolesani E, Kempf H, Liebscher S, Schenke-Layland K, Hegermann J, Nolte L, Meyer H, de la Roche J, Thiemann S, Wahl-Schott C, Martin U, Zweigerdt R. Human heart-forming organoids recapitulate early heart and foregut development. Nat Biotechnol 2021; 39(6): 737-746

244. Kodo K, Ong SG, Jahanbani F, Termglinchan V, Hirono K, InanlooRahatloo K, Ebert AD, Shukla P, Abilez OJ, Churko JM, Karakikes I, Jung G, Ichida F, Wu SM, Snyder MP, Bernstein D, Wu JC. iPSC-derived cardiomyocytes reveal abnormal TGF- $\beta$ signalling in left ventricular non-compaction cardiomyopathy. Nat Cell Biol 2016; 18(10): 1031-1042

245. Mohamed TMA, Ang YS, Radzinsky E, Zhou P, Huang Y, Elfenbein A, Foley A, Magnitsky S, Srivastava D. Regulation of cell cycle to stimulate adult cardiomyocyte proliferation and cardiac regeneration. Cell 2018; 173(1): 104-116.e12
246. Mikryukov AA, Mazine A, Wei B, Yang D, Miao Y, Gu M, Keller GM. BMP10 signaling promotes the development of endocardial cells from human pluripotent stem cell-derived cardiovascular progenitors. Cell Stem Cell 2021; 28(1): 96-111.e7

247. Wimmer RA, Leopoldi A, Aichinger M, Wick N, Hantusch B, Novatchkova M, Taubenschmid J, Hämmerle M, Esk C, Bagley JA, Lindenhofer D, Chen G, Boehm M, Agu CA, Yang F, Fu B, Zuber J, Knoblich JA, Kerjaschki D, Penninger JM. Human blood vessel organoids as a model of diabetic vasculopathy. Nature 2019; 565(7740): 505-510

248. Wimmer RA, Leopoldi A, Aichinger M, Kerjaschki D, Penninger JM. Generation of blood vessel organoids from human pluripotent stem cells. Nat Protoc 2019; 14(11): 3082-3100

249. Barker N, Huch M, Kujala P, van de Wetering M, Snippert HJ, van Es JH, Sato T, Stange DE, Begthel H, van den Born M, Danenberg E, van den Brink S, Korving J, Abo A, Peters PJ, Wright N, Poulsom R, Clevers H. Lgr5 ${ }^{\text {+ve }}$ stem cells drive self-renewal in the stomach and build long-lived gastric units in vitro. Cell Stem Cell 2010; 6(1): 25-36

250. Sigal M, Logan CY, Kapalczynska M, Mollenkopf HJ, Berger H, Wiedenmann B, Nusse R, Amieva MR, Meyer TF. Stromal Rspondin orchestrates gastric epithelial stem cells and gland homeostasis. Nature 2017; 548(7668): 451-455

251. Yan KS, Janda CY, Chang J, Zheng GXY, Larkin KA, Luca VC, Chia LA, Mah AT, Han A, Terry JM, Ootani A, Roelf K, Lee M, Yuan J, Li X, Bolen CR, Wilhelmy J, Davies PS, Ueno H, von Furstenberg RJ, Belgrader P, Ziraldo SB, Ordonez H, Henning SJ, Wong MH, Snyder MP, Weissman IL, Hsueh AJ, Mikkelsen TS, Garcia KC, Kuo CJ. Non-equivalence of Wnt and R-spondin ligands during $\operatorname{Lgr}^{+}$intestinal stem-cell self-renewal. Nature 2017; 545(7653): 238-242

252. Kim KA, Kakitani M, Zhao J, Oshima T, Tang T, Binnerts M, Liu Y, Boyle B, Park E, Emtage P, Funk WD, Tomizuka K. Mitogenic influence of human R-spondin1 on the intestinal epithelium. Science 2005; 309(5738): 1256-1259

253. Schuijers J, Junker JP, Mokry M, Hatzis P, Koo BK, Sasselli V, van der Flier LG, Cuppen E, van Oudenaarden A, Clevers H. Ascl2 acts as an R-spondin/Wnt-responsive switch to control stemness in intestinal crypts. Cell Stem Cell 2015; 16(2): 158-170

254. Yin X, Farin HF, van Es JH, Clevers H, Langer R, Karp JM. Nicheindependent high-purity cultures of $\mathrm{Lgr} 5^{+}$intestinal stem cells and their progeny. Nat Methods 2014; 11(1): 106-112

255. Serra D, Mayr U, Boni A, Lukonin I, Rempfler M, Challet Meylan L, Stadler MB, Strnad P, Papasaikas P, Vischi D, Waldt A, Roma G, Liberali P. Self-organization and symmetry breaking in intestinal organoid development. Nature 2019; 569(7754): 66-72

256. Huch M, Dorrell C, Boj SF, van Es JH, Li VS, van de Wetering M, Sato T, Hamer K, Sasaki N, Finegold MJ, Haft A, Vries RG, Grompe M, Clevers H. In vitro expansion of single $\mathrm{Lgr}^{+}$liver stem cells induced by Wnt-driven regeneration. Nature 2013; 494(7436): 247-250

257. Lin Y, Fang ZP, Liu HJ, Wang LJ, Cheng Z, Tang N, Li T, Liu T, Han HX, Cao G, Liang L, Ding YQ, Zhou WJ. HGF/R-spondin1 rescues liver dysfunction through the induction of $\mathrm{Lgr} 5^{+}$liver stem cells. Nat Commun 2017; 8(1): 1175

258. Ochoa B, Syn WK, Delgado I, Karaca GF, Jung Y, Wang J, Zubiaga AM, Fresnedo O, Omenetti A, Zdanowicz M, Choi SS, 
Diehl AM. Hedgehog signaling is critical for normal liver regeneration after partial hepatectomy in mice. Hepatology 2010; 51(5): 1712-1723

259. Langiewicz M, Graf R, Humar B, Clavien PA. JNK1 induces hedgehog signaling from stellate cells to accelerate liver regeneration in mice. J Hepatol 2018; 69(3): 666-675

260. Barker N, Rookmaaker MB, Kujala P, Ng A, Leushacke M, Snippert H, van de Wetering M, Tan S, Van Es JH, Huch M, Poulsom R, Verhaar MC, Peters PJ, Clevers H. Lgr5 ${ }^{+\mathrm{ve}}$ stem/ progenitor cells contribute to nephron formation during kidney development. Cell Rep 2012; 2(3): 540-552

261. Low JH, Li P, Chew EGY, Zhou B, Suzuki K, Zhang T, Lian MM, Liu M, Aizawa E, Rodriguez Esteban C, Yong KSM, Chen Q, Campistol JM, Fang M, Khor CC, Foo JN, Izpisua Belmonte JC, Xia Y. Generation of human PSC-derived kidney organoids with patterned nephron segments and a de novo vascular network. Cell Stem Cell 2019; 25(3): 373-387.e9

262. Wu H, Uchimura K, Donnelly EL, Kirita Y, Morris SA, Humphreys BD. Comparative analysis and refinement of human PSC-derived kidney organoid differentiation with single-cell transcriptomics. Cell Stem Cell 2018; 23(6): 869-881.e8

263. Forbes TA, Howden SE, Lawlor K, Phipson B, Maksimovic J, Hale L, Wilson S, Quinlan C, Ho G, Holman K, Bennetts B, Crawford J, Trnka P, Oshlack A, Patel C, Mallett A, Simons C, Little MH. Patient-iPSC-derived kidney organoids show functional validation of a ciliopathic renal phenotype and reveal underlying pathogenetic mechanisms. Am J Hum Genet 2018; 102(5): 816831

264. Shin K, Lee J, Guo N, Kim J, Lim A, Qu L, Mysorekar IU, Beachy PA. Hedgehog/Wnt feedback supports regenerative proliferation of epithelial stem cells in bladder. Nature 2011; 472(7341): 110-114

265. Kim E, Choi S, Kang B, Kong J, Kim Y, Yoon WH, Lee HR, Kim S, Kim HM, Lee H, Yang C, Lee YJ, Kang M, Roh TY, Jung S, $\mathrm{Kim} \mathrm{S}, \mathrm{Ku} \mathrm{JH}$, Shin K. Creation of bladder assembloids mimicking tissue regeneration and cancer. Nature 2020; 588(7839): 664-669

266. Santos CP, Lapi E, Martínez de Villarreal J, Álvaro-Espinosa L, Fernández-Barral A, Barbáchano A, Domínguez O, Laughney AM, Megías D, Muñoz A, Real FX. Urothelial organoids originating from $\mathrm{Cd} 49 \mathrm{f}^{\text {high }}$ mouse stem cells display Notchdependent differentiation capacity. Nat Commun 2019; 10(1): 4407

267. Kessler M, Hoffmann K, Brinkmann V, Thieck O, Jackisch S, Toelle B, Berger H, Mollenkopf HJ, Mangler M, Sehouli J, Fotopoulou C, Meyer TF. The Notch and Wnt pathways regulate stemness and differentiation in human fallopian tube organoids. Nat Commun 2015; 6(1): 8989

268. Xie Y, Park ES, Xiang D, Li Z. Long-term organoid culture reveals enrichment of organoid-forming epithelial cells in the fimbrial portion of mouse fallopian tube. Stem Cell Res (Amst) 2018; 32: 51-60

269. Boretto M, Maenhoudt N, Luo X, Hennes A, Boeckx B, Bui B, Heremans R, Perneel L, Kobayashi H, Van Zundert I, Brems H, Cox B, Ferrante M, Uji-I H, Koh KP, D'Hooghe T, Vanhie A, Vergote I, Meuleman C, Tomassetti C, Lambrechts D, Vriens J, Timmerman D, Vankelecom H. Patient-derived organoids from endometrial disease capture clinical heterogeneity and are amenable to drug screening. Nat Cell Biol 2019; 21(8): 1041-1051
270. Boretto M, Cox B, Noben M, Hendriks N, Fassbender A, Roose H, Amant F, Timmerman D, Tomassetti C, Vanhie A, Meuleman C, Ferrante M, Vankelecom H. Development of organoids from mouse and human endometrium showing endometrial epithelium physiology and long-term expandability. Development 2017; 144(10): 1775-1786

271. Ali A, Syed SM, Jamaluddin MFB, Colino-Sanguino Y, GallegoOrtega D, Tanwar PS. Cell lineage tracing identifies hormoneregulated and Wnt-responsive vaginal epithelial stem cells. Cell Rep 2020; 30(5): 1463-1477.e7

272. Zhang B, Ci X, Tao R, Ni JJ, Xuan X, King JL, Xia S, Li Y, Frierson HF, Lee DK, Xu J, Osunkoya AO, Dong JT. Klf5 acetylation regulates luminal differentiation of basal progenitors in prostate development and regeneration. Nat Commun 2020; 11(1): 997

273. Wang Y, Yu A, Yu FX. The Hippo pathway in tissue homeostasis and regeneration. Protein Cell 2017; 8(5): 349-359

274. Moya IM, Halder G. Hippo-YAP/TAZ signalling in organ regeneration and regenerative medicine. Nat Rev Mol Cell Biol 2019; 20(4): 211-226

275. Lian I, Kim J, Okazawa H, Zhao J, Zhao B, Yu J, Chinnaiyan A, Israel MA, Goldstein LS, Abujarour R, Ding S, Guan KL. The role of YAP transcription coactivator in regulating stem cell selfrenewal and differentiation. Genes Dev 2010; 24(11): 1106-1118

276. Qin H, Blaschke K, Wei G, Ohi Y, Blouin L, Qi Z, Yu J, Yeh RF, Hebrok M, Ramalho-Santos M. Transcriptional analysis of pluripotency reveals the Hippo pathway as a barrier to reprogramming. Hum Mol Genet 2012; 21(9): 2054-2067

277. Qin H, Hejna M, Liu Y, Percharde M, Wossidlo M, Blouin L, Durruthy-Durruthy J, Wong P, Qi Z, Yu J, Qi LS, Sebastiano V, Song JS, Ramalho-Santos M. YAP induces human naive pluripotency. Cell Rep 2016; 14(10): 2301-2312

278. Heng BC, Zhang X, Aubel D, Bai Y, Li X, Wei Y, Fussenegger M, Deng X. Role of YAP/TAZ in cell lineage fate determination and related signaling pathways. Front Cell Dev Biol 2020; 8: 735

279. Hong AW, Meng Z, Guan KL. The Hippo pathway in intestinal regeneration and disease. Nat Rev Gastroenterol Hepatol 2016; 13(6): 324-337

280. Driskill JH, Pan D. The Hippo pathway in liver homeostasis and pathophysiology. Annu Rev Pathol 2021; 16(1): 299-322

281. Elbediwy A, Vincent-Mistiaen ZI, Spencer-Dene B, Stone RK, Boeing S, Wculek SK, Cordero J, Tan EH, Ridgway R, Brunton VG, Sahai E, Gerhardt H, Behrens A, Malanchi I, Sansom OJ, Thompson BJ. Integrin signalling regulates YAP and TAZ to control skin homeostasis. Development 2016; 143(10): 1674-1687

282. Wang J, Liu S, Heallen T, Martin JF. The Hippo pathway in the heart: pivotal roles in development, disease, and regeneration. Nat Rev Cardiol 2018; 15(11): 672-684

283. He X, Zhang L, Queme LF, Liu X, Lu A, Waclaw RR, Dong X, Zhou W, Kidd G, Yoon SO, Buonanno A, Rubin JB, Xin M, Nave KA, Trapp BD, Jankowski MP, Lu QR. A histone deacetylase 3dependent pathway delimits peripheral myelin growth and functional regeneration. Nat Med 2018; 24(3): 338-351

284. Zanconato F, Cordenonsi M, Piccolo S. YAP/TAZ at the roots of cancer. Cancer Cell 2016; 29(6): 783-803

285. Erickson JR, Echeverri K. Learning from regeneration research organisms: the circuitous road to scar free wound healing. Dev Biol 
2018; 433(2): 144-154

286. Taha IN, Naba A. Exploring the extracellular matrix in health and disease using proteomics. Essays Biochem 2019; 63(3): 417-432

287. Doyle JJ, Gerber EE, Dietz HC. Matrix-dependent perturbation of TGF $\beta$ signaling and disease. FEBS Lett 2012; 586(14): 2003-2015

288. Argyropoulos AJ, Robichaud P, Balimunkwe RM, Fisher GJ, Hammerberg C, Yan Y, Quan T. Alterations of dermal connective tissue collagen in diabetes: molecular basis of aged-appearing skin. PLoS One 2016; 11(4): e0153806

289. Vigneswari S, Chai JM, Kamarudin KH, Amirul AA, Focarete ML, Ramakrishna S. Elucidating the surface functionality of biomimetic RGD peptides immobilized on nano-P(3HB-co-4HB) for H9c2 myoblast cell proliferation. Front Bioeng Biotechnol 2020;

\section{8: 567693}

290. Masaeli E, Nasr-Esfahani MH. An in vivo evaluation of induced chondrogenesis by decellularized extracellular matrix particles. J Biomed Mater Res A 2021; 109(5): 627-636

291. Yen YH, Pu CM, Liu CW, Chen YC, Chen YC, Liang CJ, Hsieh JH, Huang HF, Chen YL. Curcumin accelerates cutaneous wound healing via multiple biological actions: the involvement of TNF- $\alpha$, MMP-9, $\alpha$-SMA, and collagen. Int Wound J 2018; 15(4): 605-617

292. Fisher MB, Liang R, Jung HJ, Kim KE, Zamarra G, Almarza AJ, McMahon PJ, Woo SL. Potential of healing a transected anterior cruciate ligament with genetically modified extracellular matrix bioscaffolds in a goat model. Knee Surg Sports Traumatol Arthrosc 2012; 20(7): 1357-1365 